\title{
REgULATING HYDRAULIC FRACTURING: REGULATORY RECOURSE FOR SUBSURFACE COMMUNICATION
}

\author{
KIMBERLY HOWARD*
}

\begin{abstract}
This article provides an overview of the legal framework for the regulation of hydraulic fracturing in Alberta and examines the potential regulatory options and liability for subsurface reservoir communication caused by hydraulic fracturing activities. Specifically, this article examines the jurisdiction of the Alberta Energy Regulator (AER or the Board) to: (1) order that operations be shut-in or suspended due to subsurface reservoir communication; (2) impose obligations on industry to provide notification of hydraulic fracturing activities, including subsurface reservoir communication; (3) order mandatory commingling orders; (4) encourage production sharing agreements; and (5) impose testing, monitoring, production controls, and reporting obligations.
\end{abstract}

With the widespread use of multistage horizontal hydraulic fracturing, disputes related to subsurface communication will continue to be raised with the AER and in the courts. Thus far, the AER has taken a risk management approach through monitoring and testing requirements. Generally, the AER has permitted development to occur by endorsing an approach which relies on the known and inevitable consequences of mining and recovering the minerals. This approach has been justified by the AER on the basis that any production of another party's minerals does not result in irreparable harm. The harm or damage caused can be identified, quantified, and compensation paid.

\section{TABLE OF CONTENTS}

I. INTRODUCTION . . . . . . . . . . . . . . . . . . . . . . . . . . . . . . . . 142

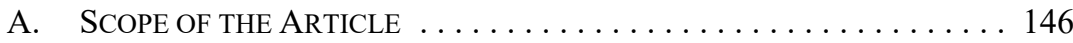

II. WHAT IS HYDRAULIC FRACTURING? . . . . . . . . . . . . . . . . . 147

III. REgUlATION OF HYdRAULIC FRACTURING IN AlBERTA . . . . . . . . . . . . 149

A. The Regulation OF OIL AND GaS

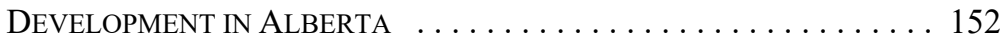

B. AER DIRECTIVES AND THE

OIL AND GAS CONSERVATION RULES . . . . . . . . . . . . . . . . 153

C. INDUSTRY STANDARDS . . . . . . . . . . . . . . . . . . 154

D. GOVERNMENT POLICY AND THE

INTEGRATED RESOURCE MANAGEMENT SYSTEM $\ldots \ldots \ldots \ldots \ldots 155$

E. AER'S PROPOSED FRAMEWORK FOR

UNCONVENTIONAL OIL AND GAS $\ldots \ldots \ldots \ldots \ldots \ldots \ldots \ldots$

F. AER REgULATIONS TARGETED AT

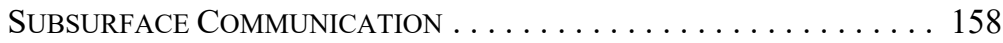

IV. REGULATORY RECOURSE FOR

SubSURFACE COMMUNICATION DisPUTES . . . . . . . . . . . . . . . . . . . 159

A. General Powers of the Alberta EnERgy Regulator . . . . . . 159

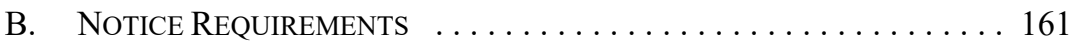

Senior Associate, McCarthy Tétrault LLP, Calgary, Alberta. The author wishes to recognize the contributions of her supervisor Professor Nigel Bankes of the University of Calgary, Faculty of Law for his patience and guidance in the preparation of this article. 


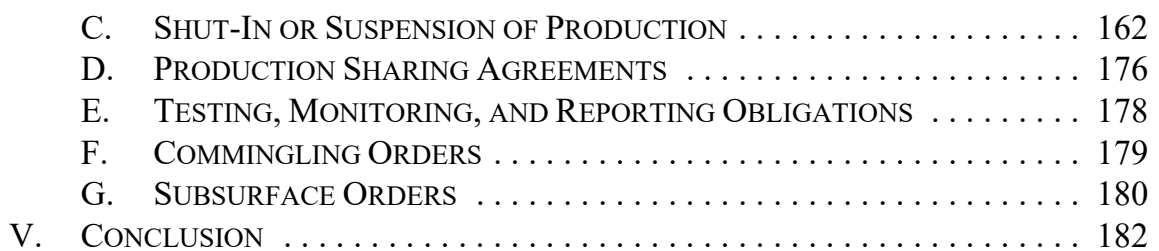

\section{INTRODUCTION}

The Alberta Energy Regulator's (AER) regulation of oil and gas is long established, and its "experience and expertise are broadly accepted by the industry." 1 Notwithstanding use of best practices and all of the current regulatory requirements, "[ $t]$ here have been occurrences of intra-zone communication between wellbores that are being hydraulically fractured and adjacent wellbores, that are either producing or being drilled, sometimes considerable distances away." "In Alberta, disputes over mineral rights ownership have arisen from hydraulic fracturing, including one instance arising from an allegation that fractures would propagate into an adjacent reservoir. ${ }^{3}$

Focusing on communication between wells, formations, or subsurface rights due to the propagation of fractures beyond intended boundaries, this article provides an overview of the legal framework for the regulation of hydraulic fracturing in Alberta, and examines the AER's powers to respond to subsurface communication disputes between industry parties. As the principal regulator of oil and gas development in Alberta, the AER can address subsurface communication disputes through various means, including the power to: (1) impose obligations for industry to provide notification of hydraulic fracturing activities, including subsurface communication; (2) order the shut-in or suspend operations due to communication; (3) order mandatory commingling; (4) issue a subsurface order; (5) encourage production sharing agreements; and (6) impose production controls and monitoring.

Communication issues can originate in many ways, including from fractures propagating beyond lease boundaries or into neighbouring formations (above or below) causing new conduits that allow the migration of oil and gas between wells or reservoirs. Additionally, water and other fluids used in the fracturing process or used in conjunction with secondary 1 Alastair R Lucas, Theresa Watson \& Eric Kimmel, "Regulating Multistage Hydraulic Fracturing: Underground: Understanding New Developments in Subsurface Production, Transmission, and Storage (New York: Oxford University Press, 2014) at 127. The Petroleum and Natural Gas Conservation Board (one of precursors to the AER) was established in 1938.

2 Alberta, Energy Resources Conservation Board, "Unconventional Gas Regulatory Framework Jurisdictional Review," Report 2011-A (Calgary: ERCB, 28 January 2011) [ERCB, "Jurisdictional Review"] at 5. See also Nigel Bankes, "Non-Conventional Oil and Gas Resources and the Legal Issues Associated with Hydraulic Fracturing in Canada" (August 2013) 15:4 International Environmental and Resources Law Committee Newsletter 4 [Bankes, "Legal Issues"] ("the Board [had] recorded 21 instances of unintentional communication between the subject well (where hydraulic fracturing is being conducted) and offset wells (wells on contiguous/adjacent properties)" at 5).

Surge Energy Inc, Application for Special Oil Well Spacing and a Review of Well Licenses and Compliance of Production Restrictions, Valhalla Field (10 June 2013), 2013 ABERCB 010, online: ERCB $<$ www.aer.ca/documents/decisions/2013/2013-ABERCB-010.pdf $>$ [Surge Energy Inc]. 
or enhanced recovery ${ }^{4}$ can migrate and interfere with the oil and gas composition, or cause drainage from outside lease boundaries or from an entirely different reservoir.

For example, if a fracture propagates into an adjacent reservoir containing sour gas with a positive pressure differential, the subsurface communication could potentially lead to the souring of gas that otherwise did not contain hydrogen sulfide within the target reservoir. ${ }^{5}$ Subsurface communication can also occur between a wellbore being stimulated and an offset energy wellbore that penetrates the same formation. ${ }^{6}$

These subsurface communication issues can cause a number of adverse effects, ${ }^{7}$ including: (1) changes in reservoir pressure and resulting production; (2) changes in oil and gas composition; (3) drainage; (4) the potential for waste or stranding of resources if there is a pressure differential between the involved reservoirs; and (5) the potential for hydrocarbons to be produced from outside the operator's legal entitlement (for example, production from a neighbouring formation or outside lease boundaries). ${ }^{8}$

Notwithstanding its various regulatory tools, the tools available to the AER may fall short in resolving communication issues, leaving participants to resolve disputes through legal proceedings drawing on common law causes of action. ${ }^{9}$ Civil disputes regarding hydraulic fracturing have focused on property, tort, and contract law. ${ }^{10}$ The question of what causes of action (regulatory or common law) and which forum (the court or the AER) will offer effective remedies for subsurface communication could have a significant impact on operations.

Oil and Gas Conservation Act, RSA 2000, c O-6, s 1(1)(r) [OGCA]. "Enhanced recovery" is defined as the increased recovery from a pool achieved by artificial means or by the application of energy extrinsic to the pool, which artificial means or application includes pressuring, cycling, pressure maintenance or injection to the pool of a substance or form of energy, but does not include the injection in a well of a substance or form of energy for the sole purpose of (i) aiding in the lifting of fluids in the well, or (ii) stimulation of the reservoir at or near the well by mechanical, chemical, thermal or explosive means.

See also AER, "Resources Applications for Oil and Gas Reservoirs," Directive 065 (Calgary: AER, 9 April 2014) [Directive 065] ("enhanced recovery (ER) improves hydrocarbon recovery by injecting fluid(s) into a hydrocarbon reservoir to [:] add to or maintain reservoir energy (pressure), displace hydrocarbons to productions wells, and/or alter the reservoir fluids so that hydrocarbon flow and recovery are improved" at 2.1.1.1).

See e.g. Surge Energy Inc, supra note 3 (Exhibit 155.02, CNRL 19 March 2013 Round 3 Evidence Submission at 7). At issue in this proceeding was, inter alia, ways to identify subsurface communication. One method that was raised was a compositional analysis in relation to past acid gas injection into one of the subject reservoirs.

ERCB, "Hydraulic Fracturing: Interwellbore Communication between Energy Wells," Bulletin 2012-002 (Calgary: AER, 23 January 2012), superseded by AER, "Hydraulic Fracturing: Subsurface Integrity," Directive 083 (Calgary: AER, 21 May 2013) [Directive 083].

7 Directive 083, ibid. See also Energy Resources Conservation Board, “A Discussion Paper: Regulating Unconventional Oil \& Gas in Alberta" (Calgary: ERCB, 2012) at 2 [ERCB, "Discussion Paper”]; Bankes "Legal Issues," supra note 2 at 5.

8 Ibid.

9 David E Pierce, "Developing a Common Law of Hydraulic Fracturing” (2011) 72:4 U Pitt L Rev 685 at 686.

$10 \quad$ Ibid. See generally Kaoru Suzuki, "The Role of Nuisance in the Developing Common Law of Hydraulic Fracturing" (2014) 41:1 Boston College Envtl Aff L Rev 265; EM Bredin, "Legal Liability for Water Flooding in Petroleum Reservoirs in Alberta" (1961) 1:6 Alta L Rev 516; Brian J Preston, "Unconventional Natural Gas in the Courts: An Overview" (2014) 32:4 J Energy \& Natural Resources L 377; P Donald Kennedy et al, "Tort Liability in Waterflood Operations" (1966) 5:1 Alta L Rev 52; Terry D Ragsdale, "Hydraulic Fracturing: The Stealthy Subsurface Trespass" (1993) 28:3 Tulsa LJ 311; Barry Barton, "The Common Law of Subsurface Activity: General Principle and Current Problems" in Donald N Zillman et al, eds, The Law of Energy Underground: Understanding New Developments in Subsurface Production, Transmission, and Storage (New York: Oxford University Press, 2014). 
At one extreme position, David E. Pierce suggests that the imposition of heavy-handed liability for hydraulic fracturing could cause operators to abandon the process:

Because it is not possible to control the precise location of fissures created by the fracturing process, imposing liability for fissures that cross property boundaries would cause operators to limit their use of hydraulic fracturing and may, ultimately, cause them to abandon the process altogether — which would mean abandoning development of most shale formations. ${ }^{11}$

Furthermore, unreasonably restricting the use of hydraulic fracturing could sterilize the unconventional resources or tight shale formations. ${ }^{12}$

On the other hand, permitting operators to produce oil and gas originating outside of the geographical or geological boundaries enumerated within the lease defeats the purpose of granting exclusive mineral rights to a particular property. ${ }^{13}$ Such a rule (the rule of capture) encourages operators to intentionally push the permitted subsurface boundaries, resulting in a race to produce which threatens overall hydrocarbon recovery. ${ }^{14}$

Such disputes raise both property and liability issues. Property issues deal with who owns the produced hydrocarbons; liability issues deal with the consequences of producing hydrocarbons that originate from another property. In addressing these issues, the rule of capture remains the default rule in Alberta. ${ }^{15}$ This rule "provides that in the event A drills a well on his own land and produces oil or gas in a manner consistent with good industry practice, then if some of that oil or gas originates from under neighbouring lands, A becomes the owner of the oil or gas so produced and is not liable to his or her neighbour."

Canadian jurisprudence has established that legislation may vary the rule of capture, ${ }^{17}$ recognizing that the OGCA, as conservation legislation, was enacted in part to change the old concept of the rule of capture to prevent undue and wasteful extraction methods. ${ }^{18}$ Examples of statutory modifications to the application of the rule of capture include: "spacing rules, target requirements, rules relating to good production practice and allowables, rateable take orders and the common orders (purchaser, carrier, and processor)."19

In the context of subsurface communication caused by hydraulic fracturing, will the rule of capture be applied as the default property and no-liability rule? To date, this question remains unanswered. How will the AER and the courts address communication caused by

Pierce, supra note 9 at 686.

Ibid.

Anderson v Amoco Canada Oil and Gas, 2004 SCC 49, [2004] 3 SCR 3 at para 39 [Anderson].

Ibid at para 37.

Cecilia A Low "'The Rule of Capture: Its Current Status and Some Issues to Consider" (2009) 46:3 Alta L Rev 799 at 799-801; Nigel Bankes, "The Rule of Capture is Not the Only No Liability Rule in the Oil and Gas Business" (16 April 2010), ABlawg (blog) at 1, online: <http://ablawg.ca/wp-content/uploads/ 2010/04/blog_nb_hunt_abqb_april2010.pdf >.

Low, ibid at 799-800 [footnotes omitted].

Imperial Oil Limited v Placid Oil Company, [1963] SCR 333.

Lickacz et al v Magna Petroleum Ltd et al (1993), 160 AR 193 (QB) at paras 49-50; Low, supra note 15 at $812-13$.

Nigel Bankes, "Legal Issues Associated with the Adoption of Commercial Scale CCS Projects" (Pembina Institute - ISEEE Thought Leader Forum, 10 November 2008) at 8, online: <https://www. pembina.org/reports/ccs-discuss-legal.pdf> 
hydraulic fracturing? Is it simply a case of a licensee exercising its right "to work, dig and use all reasonable means to recover the minerals" ${ }^{20}$ where the use of hydraulic fracturing is necessary for tight shale formations?

Taking a step back, Crown leases are three dimensional insofar as " $[\mathrm{t}]$ hey confer rights to explore for and produce hydrocarbons over a specified land area, and are either unrestricted in depth or are confined to stated geological horizons." 21 The rule of capture has historically been applied to subsurface communication between wells within the same pools or geographical and geological boundaries, or as described by the Judicial Committee of the Privy Council, "within the [same] container." 22 In other words, the rule applies where there is an overlap in the legal entitlement, such as the right to work and recover different hydrocarbons, from the same lands. ${ }^{23}$ Additionally, in limited circumstances, courts have permitted a licensee to drill below the base of the terminating formation to, among other things, accommodate the required over-hole for logging tools and casing. ${ }^{24}$

A distinction can be drawn between naturally occurring subsurface communication and subsurface communication caused artificially by hydraulic fracturing. The rule of capture applied by the Privy Council in Borys contemplated the migration of hydrocarbons within the same "container." ${ }^{25}$ Hydraulic fracturing operations have the potential to create conduits for cross-flow that did not otherwise exist within a "container" and between adjacent "containers" due to rogue fractures crossing legal and contractual boundaries. On the other hand, hydraulic fracturing is necessary to produce hydrocarbons from tight unconventional formations; therefore, the potential for fractures to extend beyond intended boundaries can also be considered a necessarily incidental consequence. If the rule of capture applies and rogue fractures are simply a necessarily incidental consequence of developing the resource, does this suggest that the law should favour a policy that permits licensees to fracture into an adjacent formation?

In summary, it remains unanswered whether or not the rule of capture (with or without modification) applies to subsurface communication caused by hydraulic fracturing. It is within this context that this article will review the available regulatory tools and how they have been used by the AER and the courts.

This article is organized into five sections. The first provides an overview of the communication issues related to hydraulic fracturing, the limits to the scope of this article, and an outline of the organization of the article. The next section provides a general overview of hydraulic fracturing, and how it is used to enhance the extraction of oil and gas from tight or unconventional formations. The third explores the current and proposed regulatory regime in Alberta for the regulation of hydraulic fracturing, with a focus on subsurface communication issues. The next section discusses some of the regulatory solutions available

Anerta Energy Co v Goodwell Petroleum Corp, 2003 ABCA 277, 233 DLR (4th) 341 at para 64 [Goodwell].

Ibid at para 3 .

Borys v CPR Co, [1953] 2 DLR 65 (PC) at 68 [Borys].

Goodwell, supra note 20 at para 80 ; Low, supra note 15 at 813 .

Xerex Exploration Ltd v Petro-Canada, 2003 ABQB 746, 343 AR 347, aff'd 2005 ABCA 224, 256 DLR (4th) 218 at para 73

Borys, supra note 22 at $67-68,72,74-75,79$. 
to the AER and industry to address subsurface communication disputes. The final section discusses some of the limits to the AER's jurisdiction, and how the AER may approach subsurface communication disputes in the future.

\section{A. SCOPE OF THE ARTicle}

Generally, litigation and regulatory proceedings relating to hydraulic fracturing can be divided into five categories: ${ }^{26}$

(1) Litigation between landowners and oil and gas companies (industry); ${ }^{27}$

(2) Litigation between rival oil and gas companies;

(3) Litigation between regulatory agencies and oil and gas companies, typically in the form of "judicial review proceedings to challenge decisions ... that relate to unconventional [oil and] gas projects or activities",28

(4) Public interest litigation involving "environmental non-governmental organizations seeking judicial review of government decisions to grant leases or approvals for unconventional [oil and] gas exploration or approval", $;{ }^{29}$ and

(5) Litigation between landowners or industry and regulatory agencies, most recently seen in Alberta with respect to regulatory negligence. ${ }^{30}$

The focus of this article will be the regulation of hydraulic fracturing in Alberta, and regulatory liability for subsurface harm and communication caused by competing industry or historic operations. This article does not address the remaining categories, which may include any common law litigation associated with claims by landowners or public interest groups regarding water contamination, waste management, fugitive gas releases, offshore development, and seismic stability. Also outside the scope of this article is the potential for claims to be made by surface owners who experience harms as a result of hydraulic fracturing operations ${ }^{31}$ (for example, storage of waste water or surface spills), as well as any contractual disputes between industry players. ${ }^{32}$

See Preston, supra note 10 at 381 (which includes a discussion of four general types of litigation with respect to unconventional gas litigation).

Ibid.

Ibid.

Ibid.

See especially Ernst v EnCana Corp, 2013 ABQB 537, 570 AR 317, aff'd 2014 ABCA 285, 580 AR 341.

Pierce, supra note 9 at 686.

Ibid at 697-98 (discussion of contractual issues associated with hydraulic fracturing). 


\section{What is HydRAUlic Fracturing?}

In order to review the regulatory tools available to address subsurface communication caused by hydraulic fracturing, a basic understanding of what hydraulic fracturing is and why it is used is necessary. This section of the article provides a brief overview of hydraulic fracturing and its use in Alberta.

Hydraulic fracturing has been used by the oil and gas industry for decades. ${ }^{33}$ Its recent popularity is due, in part, to its widespread use to extract oil and gas from unconventional formations otherwise thought undevelopable. ${ }^{34}$ In Alberta alone, approximately 171,000 wells have been drilled using some form of hydraulic fracturing since the $1950 \mathrm{~s} .{ }^{35}$ According to the AER, "[s]ince 2008, approximately 5,000 horizontal wells have been drilled in Alberta using multi-stage hydraulic fracturing to enhance oil and gas recovery." ${ }^{36}$ While hydraulic fracturing is not new, the intensity of development and innovations in hydraulic fracturing technology for developing unconventional resources have created new challenges, including "growing public concerns about the real and, in some cases, perceived, risks to human health and safety, and the potential environmental impacts, particularly on water resources.",37

In Alberta, oil and gas development has generally been classified as either conventional or unconventional. The terms "conventional" and "unconventional" refer to how the resource is produced and the type of rock in which the oil and gas is found; the chemical composition of the oil and gas is essentially the same. ${ }^{38}$ After nearly a century of conventional oil and gas production, Alberta has recently seen a decline in conventional oil and gas reserves and increased investment by industry in unconventional oil and gas reserves. ${ }^{39}$

According to the Energy Resources Conservation Board (ERCB, predecessor to the AER) Unconventional Gas Regulatory Framework, Report 2011A:

The geological and geochemical characteristics of each shale gas play are relatively unique. However, fundamental aspects of shale gas development common to other areas can be expected with shale gas development in Alberta, too. Shale gas plays cover potentially very large continuous areas, thousands to tens of thousands of square kilometres. Gas-in-place volumes are enormous, even for the smaller plays. Depths of prospective shale gas zones range from relatively shallow (less than 300 metres $[\mathrm{m}]$ ) to quite deep (greater than $3000 \mathrm{~m})$.

In Alberta, there is potential for both shallow and deep shale gas plays. Drilling long-reach horizontal wells is the preferred exploitation strategy for the deeper, thicker gas shales, where as vertical wells may more (2010) 62:12 J Petroleum Technology 26 at 27, as cited in Keith Luft, Thomas O’Leary \& Ian Laing, "Regulatory and Liability Issues in Horizontal Multi-Stage Fracturing" (2012) 50:2 Alta L Rev 403 at 405 . Luft, O’Leary \& Laing, ibid at 406; Canadian Association of Petroleum Producers, "Shale Gas," online: $<$ www.capp.ca/canadaindustry/naturalGas/ShaleGas/Pages/default.aspx.>.

Energy Resources Conservation Board, News Release, "ERCB Seeking Feedback on Regulatory Approach for Unconventional Development" (17 December 2012), online: <www.aer.ca/documents/ news-releases/NR2012-13.pdf> [ERCB, "Seeking Feedback"].

Ibid.

Lucas, Watson \& Kimmel, supra note 1 at 127.

ERCB, "Discussion Paper," supra note 7 at 2.

Ibid. 
typically be used to exploit shallower, thinner shales, such as those in eastern Alberta. Whether a well is horizontal or vertical, stimulation of the shale formation is necessary for economic production, and this is currently most commonly done by hydraulic fracturing. ${ }^{40}$

Hydraulic fracturing is required because unconventional oil and gas is found in lowpermeability rock or tight formations. In order to stimulate the oil and gas to flow up the wellbore for production, a pathway or "crack" in the rock must be created.

\begin{abstract}
Hydraulic well fracturing ("fracking") is the process of pumping fluid into a wellbore to create enough pressure to crack, or fracture, the rock layer. The fluid usually contains a "proppant," like sand, that helps keep the fractures open to allow oil and gas to be produced to the well.
\end{abstract}

To produce unconventional oil and natural gas, horizontal wells and multistage fracturing are used. These wells start by drilling vertically (straight down) and then turning the drill bit so that it drills horizontally through the formation. ${ }^{41}$

As compared to conventional, unconventional oil and gas development uses new technology, or new advances in old technology, mainly the combination of horizontal directional drilling and hydraulic fracturing, ${ }^{42}$ and "requires a greater scale of development and intensity of infrastructure ... to be economical." 43 Included within the unconventional category are shale oil and gas, coalbed methane, and tight oil and gas. ${ }^{44}$ Some authors include the oil sands within the category of unconventional; however, the regulatory framework for the oil sands is well-developed and established. ${ }^{45}$

In addition to the potential for subsurface communication between wells, formations, or other subsurface rights due to the propagation of fractures beyond intended boundaries, ${ }^{46}$ hydraulic fracturing raises a broad range of social, environmental, and legal issues, including: ${ }^{47}$

- $\quad$ Potential impacts on surface and groundwater, given the vast amounts of water required; ${ }^{48}$

$40 \quad$ Energy Resources Conservation Board, "Jurisdictional Review," supra note 2 at 3.

41 AER, "What is Hydraulic Fracturing?" (27 March 2015), online: <www.aer.ca/about-aer/spotlighton/unconventional-regulatory-framework/what-is-hydraulic-fracturing $>$.

Lucas, Watson \& Kimmel, supra note 1 at 129.

ERCB, "Discussion Paper," supra note 7 at 1.

Ibid at 2.

See e.g. Oil Sands Conservation Act, RSA 2000, c O-7; Alberta Energy Regulator, "Requirements for Inspection and Compliance of Oil Sands Mining and Processing Plant Operations in the Oil Sands Mining Area," Directive 073 (Calgary: AER, 17 December 2008) [Directive 073]; Alberta Energy Regulator, "Regulatory Application Process for Modifications to Commercial In Situ Oil Sands Projects," Directive 078 (Calgary: AER, 3 December 2010) [Directive 078]; Alberta Energy Regulator, "Water Disposal Limits and Reporting Requirements for Thermal In Situ Oil Sands Schemes," Directive 081 (Calgary: AER, 21 November 2012) [Directive 081]; Alberta Energy Regulator, "Operating Criteria: Resource Recovery Requirements for Oil Sands Mine and Processing Plant Operations,” Directive 082 (Calgary: AER, 11 April 2016) [Directive 082].

$46 \quad$ Ibid; Bankes, "Legal Issues," supra note 2 at 7-8.

47 Nova Scotia Department of Energy and Nova Scotia Environment, "Jurisdictional Review of Hydraulic Fracturing Regulation” (Nova Scotia: Nova Scotia Hydraulic Fracturing Review Committee, 2012) at 7-9 [Nova Scotia, "Jurisdictional Review"].

$48 \quad$ Ibid; Bankes, "Legal Issues," supra note 2 at 6-8; Luft, O’Leary \& Laing, supra note 33 at 409. 
- Operational and technical guidelines, such as the proper construction and design of wells, and specifically well casing and cementing to protect against water contamination and communication with other wells and formations, ${ }^{49}$

- Waste management, including the handling, storage, and disposal of fracturing fluids, and the use of deep well injection schemes, ${ }^{50}$

- $\quad$ Fugitive releases of hazardous gases, such as methane, as a by-product of its use;

- Monitoring and reporting of hydraulic fracturing practices, such as mandatory disclosure of fracture fluid compositions, ${ }^{51}$

- Seismic stability and hydraulic fracturing's relationship with increased seismicity; ${ }^{.5}$ and

- Although not applicable in Alberta, the use of hydraulic fracturing for offshore development. $^{53}$

The effects of hydraulic fracturing occur deep underneath the surface, creating factual and evidentiary difficulties in establishing whether subsurface communication issues are caused by hydraulic fracturing, and the extent and nature of any potential harm. In addition, industry treats hydraulic fracturing techniques as confidential in order to maintain a competitive advantage in the marketplace; thus little information about these techniques is publicly available. ${ }^{54}$ All of these factors make it difficult for the regulator to monitor and track hydraulic fracturing, and also for industry to delineate the effects of hydraulic fracturing and the extent of the communication issues that have resulted. Moreover, the highly technical and scientific nature of hydraulic fracturing makes it more difficult to critically evaluate the regulatory measures in place.

\section{Regulation of Hydraulic Fracturing in Alberta}

This section of the article briefly outlines the regulatory framework for hydraulic fracturing within Alberta.

Pursuant to section $92 \mathrm{~A}(1)$ of the Constitution Act, $1867,{ }^{55}$ the regulation of the exploration, development, conservation, and management of non-renewable resources falls within the exclusive jurisdiction of the province. The Province of Alberta has delegated the regulation of hydraulic fracturing to the AER under the following key statutes and the

Luft, O'Leary \& Laing, ibid at 408; Nova Scotia, "Jurisdictional Review," ibid at 7-8.

Nova Scotia, "Jurisdictional Review," ibid at 9.

British Columbia, BC Oil and Gas Commission, "Hydraulic Fracture Data," Information Bulletin INDB 2013-03 (Victoria: BC Oil and Gas Commission, 4 April 2013).

52 Bankes, "Legal Issues," supra note 2 at 6; British Columbia, BC Oil and Gas Commission, "Investigation of Observed Seismicity in the Horn River Basin"(Victoria: BC Oil and Gas Commission, August 2012).

Bankes, "Legal Issues," ibid at 4.

See ERCB, "Jurisdictional Review," supra note 2 at 7.

(UK), 30 \& 31 Vict, c 3, reprinted in RSC 1985, Appendix II, No 5. 
regulations: (1) the Responsible Energy Development Act; ${ }^{56}(2)$ the Mines and Minerals Act; ${ }^{57}$ and (3) the OGCA. ${ }^{58}$ Other key statutes include the Environmental Protection and Enhancement Act, ${ }^{59}$ the Public Lands Act,${ }^{60}$ the Surface Rights Act,${ }^{61}$ the Water Act ${ }^{62}$ and the Alberta Land Stewardship Act. ${ }^{63}$

In Alberta, regulation of hydraulic fracturing for the purpose of producing oil and gas falls within the AER's mandate, as set out in section 2(1) of REDA:

(a) to provide for the efficient, safe, orderly and environmentally responsible development of energy resources in Alberta through the Regulator's regulatory activities, and

(b) in respect of energy resource activities, to regulate

(ii) the protection of the environment, and

(iii) the conservation and management of water, including the wise allocation and use of water,

in accordance with energy resource enactments and, pursuant to this Act and the regulations, in accordance with specified enactments. ${ }^{64}$

Under REDA, the AER's authority extends (to the extent approvals under these acts relate to energy resource activities) to approvals under the Public Lands Act, the Water Act, and $E P E A .{ }^{65}$ The AER is therefore a "single window" regulator, providing all of the requisite approvals for energy resource development. The AER has jurisdiction to oversee both approvals under Part 8 of the $M M A$, the actual development, production, transportation, and processing of oil and gas under the OGCA, the Oil and Gas Conservation Rules, ${ }^{66}$ and the various Directives and regulations.

The AER's regulatory regime "was designed for conventional oil and gas development and did not fully contemplate the unique nature of unconventional gas." ${ }^{\prime 67}$ Recognizing the shift in Alberta's conventional oil and gas production and increased investment in the development of unconventional gas development (that is, coalbed methane, shale gas, and tight gas), the AER initiated a program to develop and implement a new regulatory framework for Alberta's unconventional resources (Unconventional Framework). ${ }^{68}$ To address the challenges associated with unconventional development, the AER is piloting

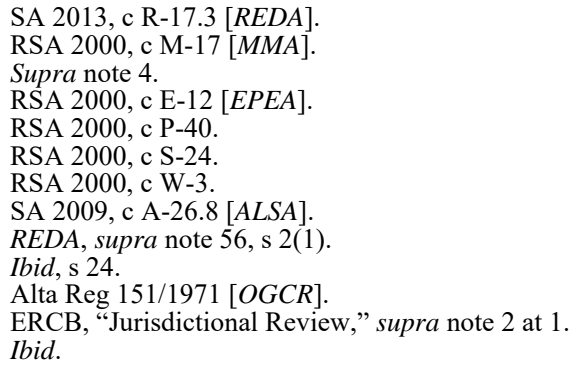


a new regulatory approach that includes moving from well-by-well regulation to regulation focused on development within a defined area. This play-focused regulation would be performance-based to achieve specific outcomes in public safety, water protection, air quality, waste management, surface impacts, resource conservation, and orderly development. ${ }^{69}$

In July 2014, the AER took the first step in implementing the Unconventional Framework by unveiling a pilot project for use in the area of the Duvernay shale play near Fox Creek, Alberta. ${ }^{70}$ By regulating unconventional development using the concept of a "play," the AER aims to address the challenges and take a holistic approach to ensure all issues and impacts are being addressed, including cumulative impacts. As described by one group of authors, unconventional resource development introduces unique challenges when compared to conventional development:

Unconventional resource development introduces unique risk characteristics and challenges which may not fit neatly within a traditional 'command and control', activities-based regulatory regime. Relative to conventional resource development:

a. the scale and intensity of development is large and more intrusive, the technology is more advanced and more complex, and reservoir management is more nuanced;

b. capital investment is large and the market conditions are more volatile;

c. greater water consumption is required;

d. development activities are more visible and are of longer duration;

e. there is a large inventory of offsetting subsurface infrastructure;

f. development often occurs proximal to populated urban and rural centers;

g. there are a large number of heterogeneous industry players with varying capabilities; and

h. there is an emerging class of the global population that is educated, politically astute, and media savvy, which has reservations about the government's and industry's capability to manage and balance the risks to social and environmental values. ${ }^{71}$

Although the proposed Unconventional Framework is not yet applicable beyond the pilot project, it is relevant to this discussion of the regulation of hydraulic fracturing, as the regulatory approach is relevant to the AER's general approach to unconventional resource development.

ERCB, "Seeking Feedback," supra note 35.

70 Alberta Energy Regulator, News Release, "Alberta Energy Regulator Pilots Play-Based Regulation Project"(2 July 2014), online: <www.aer.ca/about-aer/media-centre/news-releases/news-release-201407-02>.

71 Lucas, Watson \& Kimmel, supra note 1 at 135 


\section{A. The Regulation Of OIL ANd GaS DEVELOPMENT IN ALBERTA}

The AER has broad powers regarding the development of energy resources (conventional and unconventional) and oversees the entire life cycle of energy resource projects. These broad powers are illustrated in section 10 of the OGCA, which affords the AER the power to make rules concerning: $:^{72}$

- Conservation and the prevention of waste, "and to do any other matter reasonably incidental to the development and drilling of any oil or gas wells, the operation of them and the production from them;",73

- How wells are drilled and completed, including the minimum specifications, monitoring, materials, and other minimum requirements $;^{74}$

- The "kind and specification of tools, casing, equipment and materials that may be used for drilling, and as to the construction, alteration or use of any works, fittings, machinery, plant or appliance" used by industry in connection with "the development, production, transmission, supply, distribution, measurement, consumption or handling of any gas or oil"; ${ }^{75}$

- The strategies used by industry to confine any fluids injected underground within formations ${ }^{76}$

- “ $\quad[$ T]he location of wells and the methods of operation to be observed during drilling and in the subsequent management and conduct of any well for any purpose including ... (i) the protection of life, property and wildlife, (ii) the prevention and extinguishment of fires, and (iii) the prevention of wells blowing out of control"; ${ }^{77}$ and

- $\quad$ Required tests, analyses, surveys, monitoring, or other logs. ${ }^{78}$

Although this list is not exhaustive, it clearly demonstrates that the AER has broad powers to regulate oil and gas activities, including the licencing of wells. Pursuant to Part 6 of the OGCA, a licence is required from the AER to construct and operate petroleum industry developments, including wells. ${ }^{79}$ The completion of a well using hydraulic fracturing does not require a separate licence, but is subject to reporting requirements under the OGCR and the Directives enacted thereunder. ${ }^{80}$ In summary, no person can drill a well or undertake

OGCA, supra note 4, s 1(1)(vv.1) (the term "Regulator" is defined as the AER).

Ibid, s 10(1)(aaa).

Ibid, s $10(1)(\mathrm{o})$.

Ibid, s $10(1)(\mathrm{u})$.

Ibid, s $10(1)(\mathrm{w})$.

Ibid, s $10(1)(\mathrm{aa})$.

Ibid, s $10(1)(\mathrm{gg})$.

Ibid, Part 6.

Nova Scotia, "Jurisdictional Review," supra note 47 at 10. 
preparatory and incidental activities without the requisite licence from the $\mathrm{AER}^{81}$ which may be subject to any conditions, restrictions, or stipulations that the AER considers appropriate. ${ }^{82}$

In determining what conditions, restrictions, or stipulations may be appropriate, the AER also has the power to issue subsurface orders under section 11.104 of the OGCR. ${ }^{83}$ These newly adopted subsurface orders will be discussed below as one of the regulatory tools available to address subsurface communication disputes. Section 11.104 of the OGCR and the resulting subsurface orders are targeted at the development of tight oil and gas resources, and are intended to permit the AER to tailor regulatory requirements for specific geological zones over specified areas to better suit the resource being developed. ${ }^{84}$

\section{B. AER DIRECTIVES AND THE OIL AND GAS CONSERVATION RULES}

While its governing legislation grants broad powers to regulate the use of hydraulic fracturing as a method or technique of completing a well and stimulating production, the AER prescribes the actual details, operational, and engineering constraints in its Directives. Directives are developed with the assistance of "a wide range of technical experts-geologists, engineers, environmental scientists, and other specialized technical staff" ${ }^{\prime 85}$ and are generally incorporated into the OGCR. Pursuant to the OGCA and the OGCR, operators and licensees are required to comply with the terms and conditions of the AER's Directives ${ }^{86}$ For example, pursuant to section 3.062 of the OGCR, licensees must comply with Directive $083^{87}$ for all hydraulic fracturing operations.

Although the completion of a well using hydraulic fracturing does not require a separate licence, hydraulic fracturing is subject to certain technical and reporting obligations set out in AER Directives. ${ }^{88}$

OGCA, supra note 4, s 11 .

\section{Ibid, s 18.}

Alberta Energy Regulator,"Oil and Gas Conservation Rules Change Introducing Subsurface Orders," Bulletin 2015-05 (Calgary: AER, 10 February 2015) [Bulletin 2015-05].

Ibid (AER has indicated that these orders "will only address resource regulatory matters that are under the AER's jurisdiction. Where the orders allow increased well density, these orders will not in any way predetermine regulatory approval of wells, pipelines, other production facilities, access roads, and other surface disturbances associated with energy development of the geological zones defined in the order." See e.g. Alberta Energy Regulator, Subsurface Order No 1 (13 February 2015), online: AER <https:// www.aer.ca/documents/orders/subsurface-orders/SO1.pdf>; Alberta Energy Regulator, Subsurface Order No 2 (19 February 2015), online AER <https://www.aer.ca/documents/orders/subsurfaceorders/SO2.pdf>; Alberta Energy Regulator, Subsurface Order No 3 (17 March 2015), online: AER $<$ https://www.aer.ca/documents/orders/subsurface-orders/SO3.pdf $>$.

Alberta Energy Regulator, "How Will the AER Ensure this Activity is Safe?," online: <www.aer.ca/ about-aer/spotlight-on/unconventional-regulatory-framework/how-will-the-aer-ensure-this-activity-issafe> [AER, "Activity is Safe"].

See e.g. OGCR, supra note 66, ss 1.200, 2.010, 3.013, 3.050(2), 3.061, 3.062, 5.190(2), 6.070.

Directive 083, supra note 6.

See e.g. Alberta Energy Regulator, "Surface Casing Depth Requirements," Directive 008 (Calgary: AER, 9 December 2013) [Directive 008]; Alberta Energy Regulator, "Casing Cementing Minimum Requirements,” Directive 009 (Calgary: AER, July 1990) [Directive 009]; Alberta Energy Regulator, "Minimum Casing Design Requirements," Directive 010 (Calgary: AER, 22 December 2009) [Directive 010]; Alberta Energy Regulator, “Compliance Assurance," Directive 019 (Calgary: AER, 1 September 2010) [Directive 019]; Alberta Energy Regulator, "Injection and Disposal Wells: Well Classifications, Completions, Logging, and Testing Requirements," Directive 051 (Calgary: AER, 1 March 1994); Alberta Energy Regulator, "Storage Requirements for the Upstream Petroleum Industry," Directive 055 (Calgary: AER, December 2001); Alberta Energy Regulator, "Energy Development Applications and Schedules," Directive 056 (Calgary: AER, 1 September 2011) [Directive 056]; Alberta Energy Regulator, "Oilfield Waste Management Requirements for the Upstream Petroleum Industry," Directive 
These include: $:^{89}$

- $\quad$ Reporting requirements regarding the amounts and sources of water and chemicals used in every hydraulic fracturing operation; ${ }^{90}$

- " $[\mathrm{H}] \mathrm{ydraulic}$ fracturing fluids used above the base of groundwater protection [must] be nontoxic, and ... the operator [must] reveal the contents of the fluids to the AER upon request;",91

- The type and volume of all additives used in fracturing fluids must be recorded in the daily record of operations for any well ${ }^{92}$ and

- To prevent the fluids used in connection with hydraulic fracturing from mixing or entering groundwater or surface water, the AER requires that industry use steel casing and full cementing of the wellbore to prevent mixing in the water formations through which the wellbore may pass. ${ }^{93}$

\section{INDUSTRY STANDARDS}

Industry has also developed its own best practices and codes of conduct. The AER has acknowledged industry practices as a means to achieve its desired regulatory outcomes. ${ }^{94}$ Industry standards, although often misunderstood by the public, are a key regulatory tool as they complement the performance-based regulations. In the highly technical, commercially sensitive world of new technologies, industry's input is critical to practical and effective regulations and standards.

The Canadian Association of Petroleum Producers (CAPP) recommends the Guiding Principles and Operating Practices for Hydraulic Fracturing ${ }^{95}$ for observance by operators employing fracturing techniques. CAPP Guiding Principles require operators to commit to a number of principles with respect to: (1) safeguarding surface and groundwater; (2) measurement and disclosure of water use; (3) developing fluid additives with the least environmental risks; (4) disclosing fracturing fluid additives; and (5) continued advancement, collaboration and communication of best practices to reduce environmental risks. ${ }^{96}$

058 (Calgary: AER, 1 February 2006); Alberta Energy Regulator, "Well Drilling and Completion Data Filing Requirements," Directive 059 (Calgary: AER, 19 December 2012) [Directive 059]; Alberta Energy Regulator, "Upstream Petroleum Industry Flaring, Incinerating, and Venting," Directive 060 (Calgary: AER, 22 March 2016); Alberta Energy Regulator, "Emergency Preparedness and Response Requirements for the Petroleum Industry," Directive 071 (Calgary: AER, 24 November 2009). AER, "Activity is Safe," supra note 85

Alberta Energy Regulator, "Baseline Water Well Testing Requirements for Coalbed Methane Wells Completed Above the Base of Groundwater Protection," Directive 035 (Calgary: AER, 8 May 2006) [Directive 035].

AER, "What is Hydraulic Fracturing?," supra note 41. See also Directive 008, supra note 88.

Directive 059, supra note 88 at 3; AER "What is Hydraulic Fracturing?," ibid.

Directive 008, supra note 88; Directive 009, supra note 88; Directive 010, supra note 88; AER "What is Hydraulic Fracturing?," ibid.

ERCB, "Discussion Paper," supra note 7 at 11.

Canadian Association of Petroleum Producers, Guiding Principles for Hydraulic Fracturing (Calgary: CAPP, 2012), online: <www.capp.ca/publications-and-statistics/publications/218125> [CAPP Guiding Principles].

Ibid. 
CAPP has also asked its members to voluntarily disclose additives used in fracturing operations, and supports efforts by provincial governments to render disclosure mandatory. ${ }^{97}$ While the CAPP Guiding Principles are not legally binding, they have become industry standard, are generally followed and complied with, and have been recognized by the AER for consideration in the development of the proposed Unconventional Framework.

A second example of industry practices, albeit less formal or prescriptive, is the Petroleum Services Association of Canada's (PSAC) Hydraulic Fracturing Code of Conduct, ${ }^{98}$ which was collaboratively developed by 11 companies that perform hydraulic fracturing operations in Canada. ${ }^{99}$ The 11 companies have committed to focus their collective efforts to achieve the goal of "ensur[ing] operational excellence ... while delivering long-term social benefits in a manner that supports the interests of all stakeholders" ${ }^{\prime 00}$ in five key areas: (1) water and the environment; (2) fracturing fluid disclosure; (3) technology development; (4) health and safety training; and (5) community engagement. ${ }^{101}$ While arguably not industry standard yet, this second industry initiative is an example of performance outcomes industry is willing to commit to.

In summary, industry's voluntary development of best practices could play a significant role in ensuring "orderly and responsible development." 102 In a highly technical and confidential industry, such standards play a crucial role in determining benchmarks for industry to achieve, as well as benchmarks for the elements of common law causes of action, such as the standard of care in negligence. ${ }^{103}$

\section{Government Policy AND The INTEGRATED RESOURCE MANAGEMENT SYSTEM}

The introduction of REDA, and the creation of the AER as the single regulatory body for the regulation of oil, gas, oil sands, and coal development, were just two of the Government of Alberta's steps toward implementing its policy of an integrated resource management system or management-based approach to regulatory intervention. ${ }^{104}$ Other examples of the Government of Alberta's integrated resource management policy include Alberta's "Water

Canadian Association of Petroleum Producers, News Release, "Industry Establishes Canada-wide Operating Practices for Shale, Tight Natural Gas Hydraulic Fracturing" (30 January 2012), online: CAPP $<$ www.capp.ca/media/news-releases/industry-establishes-canada-wide-operating-practices-for-shaletight-natural-gas-hydraulic-fracturing $>$.

Petroleum Services Association of Canada, Hydraulic Fracturing Code of Conduct (2013), online: $<$ www.oilandgasinfo.ca/working-energy-commitment/hydraulic-fracturing-code-of-conduct/>. [PSAC Code].

bid (participating companies: Baker Hughes Canada, Calfrac Well Services, Canyon Technical Services, Element Technical Services, Gasfrac Energy Services, Halliburton Group Canada, Iron Horse Energy Services, Millennium Stimulation Services, Sanjel Corporation, Schlumberger Canada, and Trican Well Service).

Ibid.

Ibid at $1-2$.

Alberta Energy Regulator, "Play-Based Regulation Pilot Application Guide," Manual 009 (Calgary: AER, 3 September 2014) at 1 [AER, "Pilot Application Guide"].

Lucas, Watson \& Kimmel, supra note 1 at 138-39.

AER, "Pilot Application Guide," supra note 102 at 1. 
for Life" strategy, ${ }^{105}$ and the "Land Use Framework." 106 The Government of Alberta has also set outcomes that resource activities must comply with for air, land, and water. ${ }^{107}$

The play-based pilot project for unconventional development is one way the AER is attempting to "manage the cumulative effects of development on air, land, and water." 108 As acknowledged by the AER, some of the Government of Alberta's policy outcomes and objectives have not been fully developed. Any changes will be implemented and added to the AER's proposed Unconventional Framework as it is finalized, ${ }^{109}$ and considered in the evaluation of the AER's new pilot project. Another example is the AER's new subsurface orders, which provide regulatory requirements for specific geological zones over specified areas to better suit the resource being developed. ${ }^{110}$

\section{E. AER'S PROPOSED FRAMEWORK FOR UNCONVENTIONAL OIL AND GAS}

As discussed above, the AER has recognized that the existing framework for conventional oil and gas development must change to respond to the "unique issues, risks, opportunities, and challenges posed by unconventional resource development" created by the proposed Unconventional Framework. ${ }^{111}$ Since the release of the Unconventional Framework, the AER has unveiled a pilot project in a defined area of the Province.

The AER's Discussion Paper set out a framework, and lofty policy goals, to be achieved under this new regulatory regime. Using the principles of risk-based and play-focused regulation, ${ }^{112}$ the Discussion Paper sets the following goals, aiming the new framework to:

- $\quad$ clearly identify and mitigate potential risks to public safety, the environment, and the resource;

- $\quad$ ensure orderly development; and,

- $\quad$ avoid imposing unnecessary regulatory burden on industry. ${ }^{113}$

Government of Alberta, "Water for Life: A Renewal" (Edmonton: Government of Alberta, November 2008).

Government of Alberta, "Land-Use Framework" (Edmonton: Government of Alberta, December 2008); ALSA, supra note 63.

AER, "Pilot Application Guide," supra note 102 at 4. See also Alberta, "Lower Athabasca Regional Plan, 2012-2022" (Edmonton: Government of Alberta, August 2012); Alberta, "South Saskatchewan Regional Plan, 2014-2024" (Edmonton: Government of Alberta, July 2014), approved pursuant to ALSA, ibid.

AER, "Pilot Application Guide," ibid at 5.

Ibid at 3 .

Bulletin 2015-05, supra note 83 (AER has indicated that these orders "will only address resource regulatory matters that are under the AER's jurisdiction. Where the orders allow increased well density, these orders will not in any way predetermine regulatory approval of wells, pipelines, other production facilities, access roads, and other surface disturbances associated with energy resource development of the geological zones defined in the order" at 1). See e.g. Subsurface Order No 1, supra note 84; Subsurface Order No 2, supra note 84; Subsurface Order No 3, supra note 84.

ERCB, "Discussion Paper," supra note 7 at 2.

Ibid (ERCB defined "risk-based regulation" as "regulatory responses that are proportional to the level of risk posed by energy development" and "play-focused regulation" as "regulatory solutions that are tailored to an entire 'play' to achieve specific environmental, economic, and social outcomes" at 2). Ibid. 
In comparison to the current regime for conventional oil and gas, which is based upon well-by-well development for each individual activity, the proposed framework and the new pilot project use the concept of a "play":

[A]n area of oil and gas development that is determined mainly by geology, geographic area, the properties of the resource, and the technology required to develop that resource. Surface impacts are also considered where different land uses may be affected to a greater or lesser degree by unconventional development. The play concept differs from the current regulatory model where development generally occurs on a well-bywell basis. Under the new framework, the ERCB will formally declare plays based on their unique qualities and the level of risk that development of the play could pose. ${ }^{114}$

The AER requires development plans for each "play," and will require industry to develop development plans to address the key challenges: water management, surface infrastructure development, subsurface reservoir management, stakeholder engagement, and life cycle wellbore integrity. ${ }^{115}$

Using a performance-based regulatory approach rather than prescribing exactly how the regulatory outcome must be achieved, ${ }^{116}$ the AER is placing a heavy onus and reliance on industry developed multi-operator development plans. These plans must address the key challenges of unconventional development. ${ }^{117}$ In contrast, the current regulatory regime requires approval for each project activity, ${ }^{118}$ and cooperation and collaboration among operators within a play has not been the norm. Accordingly, to ease the transition, the AER's pilot has been calling for a project plan to be developed by individual lease holders. These development plans must address the same key challenges as the play development plans. ${ }^{119}$ Further, while not explicitly stated in all of the AER's communication, these play-based plans will need to incorporate any restrictions, terms, or objectives imposed by any applicable regional plans under the Alberta Land Stewardship Act.

In addition to play-based plans and cooperation among lease holders, the Unconventional Framework attempts to address one of the challenges related to unconventional development and the need for a higher density of wells than is permitted under the conventional framework. Unlike unconventional oil and gas development, multiple wells can be drilled at one well pad, with each well extending deep underneath the surface horizontally in multiple directions to access the oil and gas in the tight formations. ${ }^{120}$ Typical conventional reservoirs are permitted one well per section for gas reservoirs and one well per quarter section for oil. ${ }^{121}$

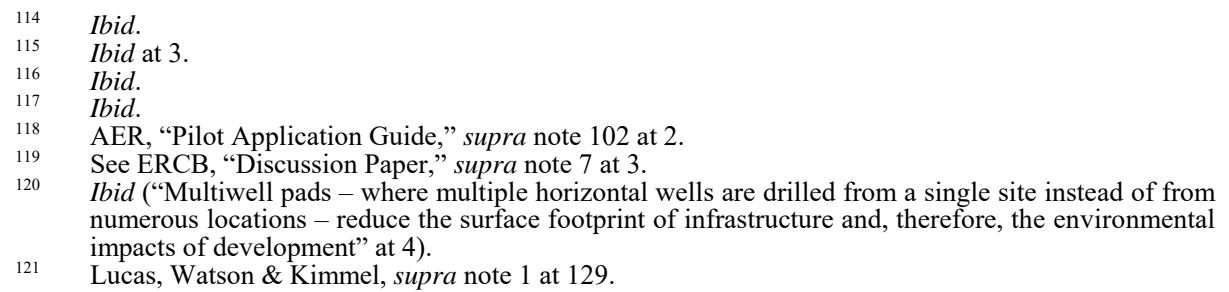


The final key feature of the proposed Unconventional Framework is the important role of compliance and outcome assurance within the play-focused regulatory program. ${ }^{122}$ Compliance assurance will be critical to ensuring that the performance-based regulatory approach is working and achieving the desired outcomes.

\section{F. AER REgulations TARgeted AT SUBSURFACE COMMUNiCATION}

The AER has flagged issues relating to wells stimulated with hydraulic fracturing including subsurface communication, and has acknowledged that "[s]ome of these matters may require additional research and field work" including:

- potential cross flow of fluids from one subsurface geological formation to another,

- wellbore completion design and operations to prevent unintended pressure communication to offset energy wells penetrating the same geological formation,

- chemical use during hydraulic fracturing operations,

- fluids and waste management, and

- prolonged venting and flaring. ${ }^{123}$

Although not explicitly in response to the Unconventional Framework, the AER has taken steps to address these issues. Two examples of steps taken are Directive 083, which was introduced in 2013, and its new power under section 11.104 of the OGCR to issue subsurface orders.

Directive 083 includes as a regulatory objective, "[t]o reduce the likelihood of unintentional interwellbore communication between a subject well and an offset well ... [and to] manage well control at an offset well in the event of interwellbore communication with a subject well." 124 Second, and as will be discussed in detail below, the AER now has the power to issue subsurface orders, which are intended to impose specific subsurface regulatory requirements for specific zones to better suit the challenges associated with the development of tight oil and gas resources. ${ }^{125}$

In summary, the AER's regulation of subsurface communication has focussed on seismic monitoring in response to concerns over seismic events, ${ }^{126}$ and requirements aimed at reducing the likelihood of unintentional interwellbore communication. ${ }^{127}$ Further, the AER's recent developments have been aimed at tailoring the regulatory requirements to the unique

ERCB, "Discussion Paper," supra note 7 at 4-5.

Ibid at 8.

Directive 083, supra note 6, s 3.2.

Bulletin 2015-05, supra note 83 .

Subsurface Order No 2, supra note 84.

Directive 083, supra note 6, s 3.2. 
challenges of unconventional development, as seen in the play-based approach and its use of subsurface orders.

\section{REGULATORY RECOURSE FOR SubSURFACE COMMUNiCATION DisPUTES}

So what can the AER do when approached by industry with a subsurface communication dispute? What regulatory options does a licensee have if it is affected by subsurface communication? This section will briefly outline the AER's general powers, as well as certain specific regulatory tools.

\section{A. General Powers of the Alberta EnERgy Regulator}

The AER has broad powers to regulate activities surrounding the development of conventional and unconventional oil and natural gas in Alberta. For the purpose of this article, these general powers can be classified as procedural or substantive. The procedural powers relevant to this analysis are those that provide both the AER and competing industry with the requisite notice and procedure by which concerns and objections can be raised and addressed. The substantive powers are those that permit the AER to impose requirements and directions and to approve activities.

Substantively, in addition to its power to make rules under section 10 of the OGCA, the AER has the power to make any and all orders necessary to carry out the purposes of its governing legislation, ${ }^{128}$ including "to provide for the efficient, safe, orderly and environmentally responsible development of energy resources in Alberta through the Regulator's regulatory activities." "129

Pursuant to section 94 of the OGCA, "the [AER] has exclusive jurisdiction to examine, inquire into, hear and determine all matters and questions arising under [the OGCA]." ${ }^{130}$ This broad mandate includes the exclusive and comprehensive jurisdiction over issues respecting conservation and prevention of waste, including the power to postpone, curtail, or prevent production. ${ }^{131}$ The AER can rely on these powers to intervene if one operator's unconventional development results in rogue fractures propagating outside the boundaries of its lease, causing the draining or depleting of the reservoir pressure of another formation, such that oil and gas could be left stranded. In fact, the AER's mandate over conservation and the prevention of waste ${ }^{132}$ is complemented by various sections of the OGCA, including

\footnotetext{
128 REDA, supra note 56, s 14.

129 Ibid, s 2(1)(a).

130 OGCA, supra note 4, s 94.

131 Giant Grosmont Petroleums Ltd et al v Gulf Canada Resources Ltd et al, 2001 ABCA 174, 286 AR 146 at para 42 [Giant Grosmont].

132 OGCA, supra note 4, ss $1(1)(\mathrm{ccc}), 1(1)(\mathrm{ddd})$ (section $1(1)(\mathrm{ccc})$ defines "waste" as "in addition to its ordinary meaning, [waste] means wasteful operations;" and section 1(1)(ddd) defines "wasteful operations" as:
}

(i) the locating, spacing, drilling, equipping, completing, operating or producing of a well in a manner that results or tends to result in reducing the quantity of oil or gas ultimately recoverable from a pool under sound engineering and economic principles,

(ii) the locating, drilling, equipping, completing, operating or producing of a well in a manner that causes or tends to cause excessive surface loss or destruction of oil or gas, 
section 107 , which provides that "any person who commits waste is guilty of an offence."133 Furthermore, section 38 of the OGCA permits the AER, with the approval of the Lieutenant Governor in Council, to require enhanced recovery operations and gas injection for underground storage. ${ }^{134}$ Enhanced recovery schemes (for example, water flooding) are often required for the efficient recovery of tight oil and gas. ${ }^{135}$

Procedurally, the AER is obligated to assess objections to applications and has the power to reconsider its own decisions, either on its own accord or as part of a request by an "eligible person" "136 for a regulatory appeal. In response, the AER has the power to reconsider an approval and where appropriate impose additional conditions, reject an application, or rescind or confirm an existing authorization.

Specifically, section 43 of REDA grants the AER the ability to reconsider its decisions, including to confirm, vary, suspend, or revoke a licence. In addition, under Divison 3 of $R E D A$, industry parties can request a regulatory appeal of a decision (for example, issuance of a licence under OGCA) made without a hearing. ${ }^{137}$ Therefore, competing industry players concerned about subsurface communication could bring an application to the Board to review a licence and request that the Board vary, suspend, or revoke the licence. ${ }^{138}$

Where a licence or approval is still in the application stage, a party who believes that it is directly affected by subsurface communication, or the potential for subsurface communication, can object to the application by filing a statement of concern with the AER. $^{139}$

(iii) the inefficient, excessive or improper use or dissipation of reservoir energy however caused,

(iv) the failure to use suitable enhanced recovery operations in a pool when it appears probable on the basis of available information that those methods would result in increasing the quantity of oil or gas ultimately recoverable from the pool under sound engineering and economic principles,

(v) the escape or the flaring of gas, if it is estimated that, in the public interest and under sound engineering principles and in the light of economics and the risk factor involved, the gas could be gathered, processed if necessary, and it or the products from it marketed, stored for future marketing, or beneficially injected into an underground reservoir,

(vi) the inefficient storing of oil or gas, whether on the surface or underground, or

(vii) the production of oil or gas in excess of proper storage facilities or of transportation and marketing facilities or of market demand for it.

Ibid, s 107. See also ibid, s 110: "[a] person who is guilty of an offence ... is liable (a) in the case of a corporation, to a fine of not more than $\$ 500,000$, and (b) in the case of an individual, to a fine of not more than $\$ 50,000$." Such liability extends for each day or part thereof that the offence is committed or continued; Directive 019, supra note 88.

OGCA, ibid, s 58 .

B Todd Hoffman, "Modeling Examines Gas Injection Results For Improving Bakken Recovery," The American Oil and Gas Reporter (June 2014), online: <www.aogr.com/magazine/cover-story/modelingexamines-gas-injection-results-for-improving-bakken-recovery $>$.

$R E D A$, supra note $56, \mathrm{~s} 36$ (to request a regulatory appeal, a party must qualify as an "eligible person" which includes "a person who is directly and adversely affected by a decision" at s 36(b)).

Ibid at Division 3.

Ibid, s 41(2). See also ibid, s 36 (to request a regulatory appeal, a party must qualify as an "eligible person" which includes "a person who is directly and adversely affected" by an "appealable decision." Further, a request for a regulatory appeal must be completed in accordance with REDA and the applicable regulations, specifically in accordance with the Alberta Energy Regulator Rules of Practice, Alta Reg 99/2013 [AER Rules of Practice]).

Shaun Fluker, "Public Participation at the Alberta Energy Resources Conservation Board" (2011) 111 Canadian Institute of Resources Law 1 at 4; Nigel Bankes, "Directly and Adversely Affected: The Actual Practice of the Alberta Energy Regulator" (3 June 2014), ABlawg (blog), online: <http:// ablawg.ca/wp-content/uploads/2014/06/Blog NB AER June-2014.pdf $>$; REDA, supra note 56, s 32 ("A person who believes that the person may be directly and adversely affected by an application may file a statement of concern with the Regulator in accordance with the rules"); AER Rules of Practice, ibid, ss 5.3-7. 
Assuming the industry party can pass the AER's test for standing, ${ }^{140}$ either the filing of a statement of concern or a request for a regulatory appeal will trigger the AER's processes, including alternative dispute resolution ${ }^{141}$ or even a full hearing. Both avenues provide the platform for the AER and industry parties to use applicable regulatory tools to address the subsurface communication.

In summary, under the umbrella of the AER's procedural and substantive powers, the AER has a number of options to address subsurface communication disputes between industry parties. The next section of this article will discuss these tools, and specifically, the AER's ability to: (1) impose obligations for industry to provide notification of hydraulic fracturing activities, including subsurface communication; ${ }^{142}$ (2) shut-in or suspend operations; ${ }^{143}$ (3) order mandatory commingling orders; ${ }^{144}$ (4) encourage production sharing agreements; ${ }^{145}$ and (5) impose production controls and monitoring. ${ }^{146}$

\section{B. Notice REQUIREMENTS}

This section will start with the notice requirements, as these trigger the attention of competing industry participants and the AER. A licensee is required to satisfy notification and consultation requirements prior to applying for the requisite licence. ${ }^{147}$ Industry is required to develop an effective participant involvement program that includes consulting with and providing notice to parties (for example, neighbouring industry, landowners, and other government departments) whose rights may be directly and adversely affected by the nature and extent of the proposed drilling and hydraulic fracturing activities. ${ }^{148}$

Specifically, Directive 056 sets out consultation and notification requirements for the various energy developments. For example, Table 7.1 sets out the requirements for various multi-pad wells. ${ }^{149}$ While the specific provisions within Directive 083 (discussed above) are intended to manage subsurface integrity and, among other things, to "reduce the likelihood of unintentional interwellbore communication between a subject well and an offset well ... [and] manage well control at an offset well in the event of interwellbore communication with a subject well," 150 Directive 056 requires general notification for all applications. As stated in Directive 056,

[t]hese tables provide industry with a starting point for developing a participant involvement program and, as such, should not be viewed as the maximum. It is industry's responsibility to assess the area beyond the specified distance to determine if the radius recommended by Directive 056 should be expanded. It may be

Fluker, ibid at 3-5 (note that this article discussed the test under the repealed Energy Resources Conservation Act, RSA 2000, c E-10, as repealed by Responsible Energy Development Act General Regulation, Alta Reg 90/2013 [REDA Regulation]. However, the principles are illustrative).

See also REDA Regulation, ibid, $\mathrm{s}$ 4(a).

See e.g. OGCA, supra note 4, ss 10, 18; OGCR, supra note 66, Part 2.

See e.g. OGCA, ibid, ss 16, 44.

See e.g. OGCA, ibid, ss 10, 18; OGCR, supra note 66 , s 3.050 .

See e.g. REDA, supra note 56, s 14.

See e.g. OGCA, supra note 4, ss 10, 18; OGCR, supra note 66.

Directive 056, supra note 88.

Ibid at 2-1.

Ibid at 7-4.

Directive 083, supra note 6 at 2 . 
necessary to increase the radius to include public interest groups or others who have expressed an interest in development in the area. ${ }^{151}$

In determining who must be notified of the intended operations, "[ $\mathrm{t}] \mathrm{he}$ applicant must also include those people that it is aware of who have concerns regardless of whether they are inside or outside the radius of personal consultation and notification indicated in Tables 5.1, 6.1, 6.2, and 7.1."152

Therefore, if the potential for communication exists, or communication has been identified, the impacted offset wells and current industry parties who may be impacted must be notified. Failure to provide such notification can result in the AER taking compliance measures pursuant to Directive 019, ${ }^{153}$ which could include shutting-in production until notification and resolution of the issues has occurred.

This mandatory notification can become a powerful tool for competing industry parties with concerns over fracturing activities. An operator concerned about communication with its mineral rights can monitor for development applications by the neighbouring operators. If communication is a concern, the operator can file a statement of concern with the AER alleging that it may be affected by the application with the intention of gaining standing to object to the proposed project. ${ }^{154}$ Once a statement of concern has been filed the applicant licensee has arguably been put on notice, and the neighbouring operator can continue to file statements of concern to all subsequent applications within the area. This concerned party is entitled to notice of any subsequent development application within the area, regardless of whether it was initially included within the enumerated class of parties to which notification or consultation is required under the specific tables. ${ }^{155}$

Further, the filing of a statement of concern results in a non-routine application, and can trigger the AER's hearing and alternative dispute resolution processes. ${ }^{156}$ These notification requirements have the potential to be a powerful negotiation tool and a way to block and delay competing industry players. They can also serve as an incentive for parties to enter into production sharing agreements where communication is alleged or occurring. In addition, the regulatory processes triggered serve as avenues for the concerned party to press for the inclusion of appropriate conditions in any licence in order to protect its interests. It may also lead to settlement negotiations between the parties.

\section{Shut-In OR Suspension of Production}

The AER can order that a well be shut-in or suspended: (1) where a licensee, approval holder, contractor, or operator has contravened the $O G C A ;{ }^{157}(2)$ where a person lacks the necessary licence for recovery of oil, gas, or bitumen from specific geographical and

Directive 056 , supra note 88 at 2-2.

Ibid.

Directive 019, supra note 88 .

REDA, supra note 56, s 32; AER Rules of Practice, supra note 138, Part 1, ss 5.3-7.5.

Directive 056, supra note 88 at 2-2.

Ibid at 2-9.

OGCA, supra note 4 , s 44 . 
geological boundaries; ${ }^{158}$ and (3) for conservation and the prevention of waste. ${ }^{159}$ This section of the article will explore the AER's power to shut-in or suspend production, including examples of its application and how this power may be applied to subsurface communication disputes caused by hydraulic fracturing.

Section 44 of the OGCA gives the AER the authority to shut-in production where "a licensee, approval holder, contractor or operator of a well or facility has contravened or failed to comply"160 with the OGCA or any of its regulations or where a method or practice employed or any equipment or installation at a well or facility is improper, hazardous, inadequate, or defective:

Where the Regulator or its authorized representative determines that a licensee, approval holder, contractor or operator of a well or facility has contravened or failed to comply with this Act, the regulations or rules or an order of the Regulator, or that a method or practice employed at a well or facility or any equipment or installation at a well or facility is improper, hazardous, inadequate or defective,

(a) the Regulator or its authorized representative may order the well or facility to be shut down or closed,

(b) the Regulator or its authorized representative may require that approved methods be adopted and that remedial measures be taken before any operation proceeds at the well or facility, or

(c) the Regulator may hold an inquiry into the matter. ${ }^{161}$

In addition, pursuant to section 16 of the OGCA, the AER can suspend or shut-in production where a person lacks the requisite licence. Generally, the production of hydrocarbons from a reservoir for which a person does not hold a production right may result in the AER cancelling or suspending the licence on any terms and conditions it deems appropriate. Specifically, section 16 reads as follows:

(1) No person shall apply for or hold a licence for a well

(a) for the recovery of oil, gas or crude bitumen, or

(b) for any other authorized purpose

unless that person is a working interest participant and is entitled to the right to produce the oil, gas or crude bitumen from the well or to the right to drill or operate the well for the other authorized purpose, as the case may be.

(2) If, after 30 days from the mailing of a notice by the Regulator to a licensee at the licensee's last known address, the licensee fails to prove entitlement under subsection (1) to the satisfaction of the Regulator,

Franco-Nevada Mining Corporation Interim Shut-in of Gas Production (2 August 2001), 2001-64, online: EUB <www.aer.ca/documents/decisions/2001/2001-64.pdf $>$ [Gas Over Bitumen Decisions]. 
the Regulator may cancel the licence or suspend the licence on any terms and conditions that it may specify. $^{162}$

In addition to sections 16 and 44 of the OCGA, the AER can also shut-in, suspend, or restrict production to prevent waste and carry out its conservation mandate. ${ }^{163}$ If the communication issues result in the stranding of any resources or wasteful operations, ${ }^{164}$ the AER, acting in the public interest, may shut-in or restrict production. As stated above, committing an act of waste is an offence pursuant to section 107 of the $O G C A .{ }^{165}$ Further, pursuant to section 108 of the OGCA, a finding of non-compliance with sections 44 and 16 of the OGCA could potentially constitute an offence. ${ }^{166}$

\section{AlBerta ENERGy RegUlator's Use OF SECTION 44 OF THE OGCA}

Section 44 of the OGCA has only been considered by the AER within the context of hydraulic fracturing in a few hearings. ${ }^{167}$ Recently, the AER considered possible communication in Kallisto Energy Corp. between a proposed conventional oil and gas well and an existing gas storage scheme. ${ }^{168}$ Kallisto Energy Corp. (Kallisto) applied for a licence to drill a vertical well for the purpose of obtaining crude oil production from the Basal Quartz Formation. CrossAlta Gas Storage \& Services Ltd., BP Canada Energy, BP Canada Energy Company, and TransCanada Pipelines Limited (collectively, CrossAlta) own and operate a gas storage scheme using the depleted Crossfield East Elkton A and D pools (the Elkton Storage Reservoir). CrossAlta objected to Kallisto's well licence application on the basis that it was concerned with the possibility of communication between its stored gas and the wellbore of the proposed Kallisto well.

Ibid, s 16 .

Goodwell, supra note 20 at paras 9-10; OGCA, ibid, s 4(a).

OGCA, ibid, s 1(1)(ddd):

"wasteful operations" means

(i) the locating, spacing, drilling, equipping, completing, operating or producing of a well in a manner that results or tends to result in reducing the quantity of oil or gas ultimately recoverable from a pool under sound engineering and economic principles,

(ii) the locating, drilling, equipping, completing, operating or producing of a well in a manner that causes or tends to cause excessive surface loss or destruction of oil or gas,

(iii) the inefficient, excessive or improper use or dissipation of reservoir energy however caused,

(iv) the failure to use suitable enhanced recovery operations in a pool when it appears probable on the basis of available information that those methods would result in increasing the quantity of oil or gas ultimately recoverable from the pool under sound engineering and economic principles,

(v) the escape or the flaring of gas, if it is estimated that, in the public interest and under sound engineering principles and in the light of economics and the risk factor involved, the gas could be gathered, processed if necessary, and it or the products from it marketed, stored for future marketing, or beneficially injected into an underground reservoir,

(vi) the inefficient storing of oil or gas, whether on the surface or underground, or

(vii) the production of oil or gas in excess of proper storage facilities or of transportation and Ibid, s 107. marketing facilities or of market demand for it.

Ibid, ss 108,110 (pursuant to section 110 of the OGCA, "[a] person who is guilty of an offence ... is liable (a) in the case of a corporation, to a fine of not more than $\$ 500,000$, and (b) in the case of an individual, to a fine of not more than $\$ 50,000$." Such liability extends for each day or part thereof that the offence is committed or continued. Further, for violations of section 16, an administrative penalty may also be imposed under REDA, supra note 56, Division 2 and the REDA Regulation, supra note 140, ss 8.1-8.3). See also Directive 019, supra note 88 .

OGCA, ibid, s 44.

Kallisto Energy Corp, Application for a Well Licence, Crossfield East Field (24 February 2012), 2012 ABERCB 005, online: ERCB < https://www.aer.ca/documents/decisions/2012/2012-ABERCB-005.pdf $>$ [Kallisto \#1]. 
The evidence presented at the hearing showed that there was some communication between the Elkton Storage Reservoir and the Basal Quartz Formation. ${ }^{169}$ Kallisto acknowledged that it had no right to produce CrossAlta's storage gas. ${ }^{170}$ After reviewing the evidence and position of the parties, the ERCB approved Kallisto's well licence application, subject to the following conditions:

(1) Kallisto should submit stabilized initial pressure data as soon as possible, (2) Kallisto must not use fracture simulation exceeding 40 tonnes without the consent of the Board, and (3) Kallisto must submit stabilized pre- and post-fracture pressure data. ${ }^{171}$

In relation to communication issues and hydraulic fracturing, the Board assessed the risk of communication as low and determined that the risk could be managed. ${ }^{172}$ Rather than deny approval of the well, the ERCB conditioned the well licence. ${ }^{173}$ Significantly, and in support of the availability of a shut-in order where there is communication, the Board found that it would order a shut-in without fracture treatment if it turned out that the well was a gas well and its pressure tests indicated communication with the Elkton Storage Unit. ${ }^{174}$ The AER's willingness to shut-in production if fracturing activities resulted in the production of storage gas suggests that in this case the Board did not consider that Kallisto had the right to produce storage gas, especially if that stored gas could be produced as a result of communication created by Kallisto's fracking activities.

Finally, in the absence of clear technical information as to the existence of communication, the Board balanced the risks by conditioning the approvals with mandatory monitoring and testing. In doing so, it clearly favoured the incumbent operation (which in this case happened to be a storage operation). Whether this decision has broader implications depends upon what analogies can be drawn. Arguably, subsurface communication with an approved storage gas scheme is unique, and this decision can be distinguished on that basis. To date, the only judicial decision considering section 44 of the OGCA is Goodwell, ${ }^{175}$ which involved a dispute between Alberta Energy Co. (AEC) and Goodwell Petroleum Corp. (Goodwell) regarding the production of crude bitumen and the initial gas-cap gas. AEC and Goodwell held split-title Crown leases to the resources. AEC held the bitumen leases and Goodwell held the natural gas leases. ${ }^{176}$ Goodwell sought an order from the Alberta Energy Utilities Board (AEUB, predecessor to the AER) to shut-in AEC's production on the ground that AEC's wells were producing at an exceptionally high gas to oil ratio, meaning it was producing significant portions of the overlying natural gas or the gas-cap, for which

\footnotetext{
Ibid at para 38 .

Ibid at para 59.

Nigel Bankes, "Competing Uses of Geological Space: Resolving Conflicts Between Production and Natural Gas Storage"(29 February 2012), ABlawg (blog) at 2, online: <ablawg.ca/2012/02/29/ competing-uses-of-geological-space-resolving-conflicts-between-production-and-natural-gas-storageinterests $/>$.

Ibid; Kallisto \#1, supra note 168 at paras 78-82.

Kallisto \#1, ibid, Appendix 1.

Ibid at para 53 .

Goodwell, supra note 20.

Ibid at para 4:

[t]he separation of oil sands and natural gas rights in the same land area and geological horizon is sometimes referred to as "split title". The title status is not of concern when a gas or an oil sands accumulation is found by itself in the formation. However, accumulations of natural gas sometimes directly overlie oil sands or are in pressure communication with them through a connecting water zone in the same geological strata. These natural gas accumulations are known as "gas-caps", and the gas in them as "initial gas-cap gas."
} 
Goodwell held the mineral rights. Specifically, Goodwell applied to the AEUB to shut-in AEC's 16 horizontal bitumen wells, on the ground that AEC had been producing large volumes of Goodwell's initial gas-cap gas. ${ }^{177}$

Goodwell and AEC participated in negotiations for compensation for past natural gas production and a sharing agreement for future production, but when negotiations failed, Goodwell, concurrently with seeking an order from the AEUB, commenced an action in the Alberta Court of Queen's Bench for compensation for past natural gas production and a production sharing agreement for all future natural gas production. ${ }^{178}$

In Goodwell, the Alberta Court of Appeal considered AEUB Decision 2000-21. ${ }^{179}$ In Decision 2000-21, the AEUB had shut-in four of AEC's wells whose performance possibly indicated they were producing significant volumes of initial gas-cap gas on the basis that production from these wells could have a negative impact on overall bitumen recovery, and because it found that AEC did not have any right, under its oil sands leases, to produce initial gas-cap gas. ${ }^{180}$

Two years following Decision 2000-21, AEC applied to the AEUB to review and vary its decision. In denying this request, the Board confirmed that it had no further concerns about conservation issues for the four shut-in wells, but maintained its position that AEC was not entitled to produce the initial gas-cap gas incidental to the recovery of bitumen. ${ }^{181}$ On appeal, the Alberta Court of Appeal held that “AEC's express right to win, work, recover and remove bitumen under its oil sands leases entitles it to produce initial gas-cap gas incidental to bitumen recovery, subject to the rights Goodwell may have for compensation for the initial gas-cap gas produced." 182

The ABCA summarized the ERCB's reasons for shutting-in four of the bitumen wells that exhibited high gas to oil ratio as follows:

In Decision 2000-21, dated March 31, 2000, the Board shut in four wells ... for two reasons.

The first related to conservation of energy resources. The Board expressed concern that the disproportionately high gas-to-oil ratio seen in the wells might have a negative impact on the overall recovery of bitumen from that region by dropping the pressure in the bitumen site. The Board ordered the wells to be shut in until the impact of bitumen recovery was addressed, depletion plans were approved and other conditions were fulfilled. AEC did not challenge this portion of the decision and has since complied with these requirements.

The Board also shut in the wells because, in its opinion, AEC did not have any right, under its oil sands leases, to produce initial gas-cap gas from the four wells. AEC, relying on Borys, supra, had argued "it was

$177 \quad$ Ibid at para 8.

178 Goodwell, supra note 20 at paras 7-8. See also Bennett Jones \& Nigel Bankes, Canadian Oil and Gas, (Markham: Lexis Nexis, 1993) (loose-leaf, consulted on 14 March 2015), Dig 497. Goodwell Petroleum Corporation Ltd. Request to Shut In Bitumen Wells Wabiskaw-McMurray Oil Sands Deposit Athabasca Area - Brintnell Sector (31 March 2000), 2000-21, online: EUB <www.aer.ca/ documents/decisions/2000/2000-21.pdf $>$ [Decision 2000-21]. 
entitled to produce that quantity of gas-cap gas required to exploit its bitumen resource without consideration for the gas mineral lease owner" provided it used good production practices and reasonable, proper and accepted industry extraction techniques ... AEC acknowledged Goodwell's interest in the gas-cap and indicated it was prepared to compensate Goodwell, once the volume of produced initial gas-cap gas was determined. $^{183}$

The conservation-related reasons were found to be a valid exercise of the ERCB's jurisdiction with respect to shut-in, as the statutory framework gave the ERCB the discretion to shut-in a well on the premise that continued production may negatively affect ultimate resource recovery efforts.

But AEC's appeal related to the ERCB's decision to shut-in the wells on the premise that AEC did not have the right to produce initial gas-cap gas incidental to its bitumen production. In canvassing previous decisions on rights associated with grants of mineral rights, the $\mathrm{ABCA}$ found the ERCB's second reason (that $\mathrm{AEC}$ did not hold the requisite rights to produce the initial gas-cap gas) to be in error.

The ABCA noted that a shut-in of a well on the ground that the licensee did not hold the rights for a substance incidentally produced was at odds with established Canadian oil and gas law. This finding was based, in part, on the judgment in Borys:

Inherently the reservation of a substance, which is of no advantage unless a right to work it is added, makes the reservation useless unless that right follows the grant. The true view is that such a reservation necessarily implies the existence of power to recover it and of the right of working.

Even if it be conceded that the respective rights of the two parties are to work for and recover each his own property (i.e., in the case of the respondents, the petroleum, and in the case of the appellant, the gas), it does not follow that neither can act without the consent of the other and that only by mutual agreement can they work at all. ${ }^{184}$

Borys was confirmed by the Supreme Court of Canada in Anderson, ${ }^{185}$ wherein the Supreme Court summarized the effect of the Borys decision as follows:

In my opinion the courts below were correct to find that Borys decided the reservation of petroleum included all hydrocarbons which were in liquid phase in the ground at the time of the transaction. The Alberta courts' answer to the preliminary questions posed by Moore C.J. was:

a) The petroleum owner is entitled to all hydrocarbons which were in liquid phase at initial pool conditions, regardless of the phase they are in when recovered.

183 Ibid at paras 9-11 [footnotes omitted].

184 Borys, supra note 22 at 75, 77 [footnotes omitted].

185 Supra note 13 at para 19 (the dispute in Borys was about entitlement to all natural gas in the pool, while the dispute in Anderson was about evolved gas). 
b) The non-petroleum owner is entitled to all hydrocarbons which were in gas phase at initial pool conditions, regardless of the phase they are in at time of recovery.

This division will apply to hydrocarbons which migrate from under other lands, subject of course to any regulatory mitigation of the rule of capture. The only hydrocarbons in the well which this decision does not deal with are those which are dissolved in the connate water at initial conditions.

In the Split Title Lands at issue in this appeal, the reservation of petroleum divided the ownership interest in oil and gas on the basis of the phase the hydrocarbon was in under initial conditions at the time of the contract for the sale of the property. Any phase changes which occur after the well is drilled into a pool does not alter the ratio of ownership created by the reservation. This applies between the parties to the original contract and to those who derive their interest from these parties. ${ }^{186}$

In finding that AEC's right to recover bitumen gives it the corollary right to produce initial gas-cap gas, the Court offered the following guidance, which could be applied to communication issues caused by hydraulic fracturing:

A profit à prendre is a right to come on to an estate and capture or take a resource.... It carries with it "the right of entry and the right to remove and take from the land the ... profit and also includes the right to use such of the surface as is necessary and convenient for the exercise of the profit". Implied in this right is the ability or licence to do whatever is necessary to search for and win the substances.

In summary, a number of principles can be distilled from these cases:

1. A right to mines and minerals includes the right to work, dig and use all reasonable means to recover the minerals.

2. If mining and recovering the minerals results in a known and inevitable consequence, that consequence is construed to be an implied term, and holders of lands or other mineral rights affected by that consequence cannot enjoin mining and recovery of the minerals.

3. These principles apply to reservations of mineral title, as well as grants and leases, including crown leases. Otherwise, the mineral right would be useless, and, as a general rule, deeds should not be construed to be without effect if other equally defensible interpretations are available.

4. While a bare right to a mineral conveys a right to win, work and carry away the mineral, that power can be expanded or restricted by express wording in the deed.

There is also a fifth rule:

5. Relevant statutes, including conservation rules arising from statutes, may modify these principles. 
Mineral extraction is an invasive business, likely to interfere with someone's property rights. Nevertheless, courts grant generous rights to exploit resources, even if the operations inevitably divert percolating waters, cause mines in higher strata to collapse and produce initial gas-cap gas. In fact, the only prohibition seems to be against operations that completely destroy the surface of the land, a right that is said to be fundamental to property ownership, and even that prohibition is not absolute. The production of initial gas-cap gas incidental to bitumen recovery is inevitable, but does not result in the destruction of anything. The gas can be measured and compensation can be paid. ${ }^{187}$

As in Goodwell, the production of oil or gas from an adjacent formation or through subsurface communication caused by rogue fractures does not result in the destruction of any resources. The hydrocarbons produced can be measured, and adequate compensation can be determined by the parties or through the courts. Statutory support for the proposition that a well should not be shut-in solely on the basis of an ownership dispute was also discussed in Goodwell with reference to section 86 of the OGCA. ${ }^{188}$

Section 86(1) of the OGCA deals with disputes over entitlement to production in a tract, and requires the operator to sell the disputed production, pay cost and expenses out of the proceeds of sale, and pay the balance to the Minister to be held in trust, pending a court order or settlement by the parties. ${ }^{189}$

Section 86(1) of the OGCA, as interpreted in Goodwell, is evidence that inequitable production scenarios were indeed considered by the legislative drafters, and the authority to shut-in due to a production dispute is not included as part of the legislative remedy offered in the statute. This is further supported by the fact that the provisions authorizing shut-in within the OGCA do not address equity issues, but rather address instances where there is an unsafe condition or a breach of a statutory requirement under the OGCA or a breach of a licence, order, or direction given by the Board.

Goodwell can be distinguished from cases involving subsurface communication caused by hydraulic fracturing on the basis that it does not necessarily entail split-title. However, this decision demonstrates the regulator's and the Court's acknowledgment of the appropriateness of compensation for any incidental production. Further, because hydraulic fracturing enhances resource extraction, there is an argument in favour of hydraulic fracturing as a necessary method to avoid wasteful operations. Therefore, the potential for the fractures to propagate outside of legal boundaries is a known and inevitable consequence, and as such, is an implied term of the applicable lease and licence. Subject to some important limitations, this line of argument appears to be favoured in a recent line of decisions, which will be discussed next. 


\title{
2. AlbERTA ENERGY REGULATOR'S USE OF SECTION 16 OF THE OGCA
}

The relevant jurisprudence reveals some general principles regarding the AER's power to suspend or cancel licences pursuant to section 16 of the OGCA. Each of these principles is set out briefly below. As noted in Goodwell:

\begin{abstract}
These sections will be contravened if the person who holds the well licence does not possess the right to produce the hydrocarbon authorized by the well licence. The right to produce could be acquired by agreement, reservation, grant or, as in this case, crown lease. Again, the application of the sections depends on the interpretation of the instrument that grants the rights. The sections themselves do not further restrict the oil sands lessee's rights. ${ }^{190}$
\end{abstract}

In Desoto Resources Ltd., ${ }^{191}$ the ERCB confirmed its jurisdiction to consider whether a lease is still in force to support an entitlement to hold the well licence. The Board set out a two-stage test to determine whether to suspend or cancel a licence under section 16 of the OGCA:

It is clear to the Board that it has the jurisdiction and in this case must exercise it to determine whether Desoto has entitlement to produce from this well and, if not, what should be done with the well. The well has already been drilled and Desoto appears eager to produce it. EnCana has asked the Board to cancel the licence and suspend operations pending judicial determination of entitlement.

The Board finds that it has jurisdiction to determine whether an applicant under Section 16 of the OGCA "is entitled to the right to produce oil, gas or crude bitumen from the well..." for the purpose of granting a licence, notwithstanding that there is a bona fide ownership, proprietary, or other legal dispute over an applicant's entitlement. ${ }^{192}$

The Alberta Court of Appeal's decision in Re Bearspaw Petroleum Ltd. ${ }^{193}$ confirmed a key limit to the AER's jurisdiction. This decision involved a dispute between, among others, EnCana Corporation (EnCana), Devon Canada Corporation (Devon), and Bearspaw Petroleum Ltd. (Bearspaw) over the ownership of coalbed methane (CBM) in split-titles between coal (EnCana) and natural gas owners (Devon and Bearspaw). The Alberta Court of Appeal considered the Board's (the Energy Utilities Board (EUB)) conclusion that "the natural gas owners rather than the coal owners had CBM development rights" 194 and confirmed that the Board did "not have the authority to determine ownership or proprietary

Ibid at para 93.

Desoto Resources Ltd Section 40, Review of Well Licence No 0365128, Joffre Field (17 June 2008) 2008-047, online: AER < www.aer.ca/documents/decisions/2008/2008-047.pdf> [Desoto Resources Ltd] (involved a dispute over whether Desoto's leases were valid and whether or not Desoto could comply with section 16 of the OGCA).

Ibid at 3 [footnotes omitted].

Carbon Development Partnership v Energy and Utilities Board (Alta) et al, 2007 ABCA 343, 425 AR 222 [Re Bearspaw].

Ibid at para 7. 
disputes in a conclusive way like a court" but could make the determination for the purpose of considering section 16 of the OGCA. ${ }^{195}$

Finally, it appears that the operator has the onus to establish that it owns the oil and gas rights in the target formation ${ }^{196}$ " "to the satisfaction of the Board""197 and on a balance of probabilities. $^{198}$

In 2013, the AER had the opportunity to revisit the application of section 16 of the OGCA in relation to hydraulic fracturing activities in Kallisto Energy Corp. ${ }^{199}$ In Kallisto \#2, Kallisto applied for another well licence for the purpose of producing crude oil from the Elkton Formation. CrossAlta Gas Storage \& Services Ltd., TransCanada Pipelines Limited, and TransCanada Energy (collectively, CrossAlta) own and operate a commercial natural gas storage scheme in an Elkton Reservoir, with the nearest portion of Kallisto's well to CrossAlta's storage unit being about 290 meters. ${ }^{200}$ One difference between this application and Kallisto \#1 was that although the second proposed well was also outside the boundaries of CrossAlta's storage unit, Kallisto was proposing to produce crude oil from the Elkton Formation, the same formation which CrossAlta uses for storage. ${ }^{201}$ Another difference was that Kallisto agreed not to use hydraulic fracturing to stimulate production from the subject well. ${ }^{202}$ Therefore, although this decision involved potential subsurface communication, that communication was not due to fractures propagating into the storage reservoir, but simply proximity within the same formation.

In considering section 16 of the OGCA, the Board addressed CrossAlta's argument that Kalisto's lease did not give it the right to explore for oil in the Elkton Formation or to produce storage gas by stating that:

The AER has the jurisdiction to consider whether the applicant's rights satisfy the AER's regulatory requirements. In Decision 2007-024: Bearspaw Petroleum Ltd., Devon Canada Corporation, and Fairborne Energy Ltd., the Energy Utilities Board (predecessor to the ERCB) stated the following:

Bearspaw Petroleum Ltd, Devon Canada Corporation, and Fairborne Energy Ltd, Part 2 of Proceeding No 1457147 - Review of Certain Well Licences and Compulsory Pooling and Special Well Spacing (Holding) Orders in the Clive, Ewing Lake, Stettler, and Wimborne Fields (28 March 2007), 2007-024 at 23, online: EUB <www.aer.ca/documents/decisions/2007/2007-024.pdf $>$. CrossAlta Gas Storage Services Ltd Application for the Permanent Shut-in and Abandonment of the Crossfield East Basal Quartz A Pool, Crossfield East Field (17 November 2009), 2009-068, as cited in Lucas, Watson \& Kimmel, supra note 1 at 130. Re Bearspaw, supra note 193 at para 21.

Ibid. The Alberta Court of Appeal was considering an application for leave to appeal the decision. The Court accepted the appeal in part, but expressly addressed a number of points that they stated may not be argued in the appeal. Among these points was the Board's decision regarding the standard of proof required under section 16(2) of the OGCA. Carbon Development Partnership submitted that the Board had erred in deciding the appropriate standard was the balance of probabilities (ibid). Kallisto Energy Corp, Application for a Well Licence, Crossfield East Field (23 July 2013), 2013 ABAER 013, online: AER < www.aer.ca/documents/decisions/2013/2013-ABAER-013.pdf > [Kallisto $\# 2]$. Ibid at $1-2$.

$201 \quad$ Nigel Bankes, "Kallisto \#2. Competing Uses of Geological Space: Resolving Conflicts Between Oi Production and Natural Gas Storage Interests" (1 August 2013), ABlawg (blog), online: <ablawg.ca/ 2013/08/01/kallisto-2-competing-uses-of-geological-space-resolving-conflicts-between-oil-productionand-natural-gas-storage-interests> [Bankes, "Kallisto \#2"]

Kallisto \#2, supra note 199 at para 90. 
It is important to note that the Board is not making final or conclusive decisions that bind the parties for all purposes when it finds that an applicant is the owner or otherwise entitled to produce the resource. That ultimate authority belongs to the courts. The Board is, rather, deciding that an applicant has demonstrated entitlement to the Board's satisfaction for the purpose of issuing well licences or similar requirements under the compulsory pooling and special well spacing (holding) provisions of the OGCA and the OGCR. ${ }^{203}$

In approving Kallisto's application, the AER attached a number of conditions "relating to the manner of drilling and completing the well, abandonment of the well, measurements to be taken, the disclosure of certain confidential information about the well to both CrossAlta and neighbouring mineral owners, and production reporting requirements." ${ }^{204}$ In concluding that section 16 of the OGCA had been satisfied by Kallisto, the Board found that CrossAlta's applicable approval and "storage agreement with the Crown [did] not restrict exploration and production of hydrocarbons outside the boundaries of the approved gas storage unit, even if the Elkton Formation or the Crossfield East Elkton reservoir extend[ed] outside those same boundaries."205

On the issue of whether the AER had jurisdiction to issue the well licence to Kallisto if it expects to produce storage gas, the Board held in favour of Kallisto in finding that it may be permissible to interfere with property rights and any damage could be the subject of compensation which is beyond the jurisdiction of the AER. ${ }^{206}$ With respect to CrossAlta's claims of potential trespass and conversion, the AER properly noted that "any remedy for tortious action would be within the jurisdiction of the courts." ${ }^{207}$ Therefore, the Board in Kallisto \#2, relying on Goodwell, acknowledges that Kallisto might incidentally produce storage gas.

\section{SHUT-IN IN RESPONSE TO CONSERVATION CONCERNS}

The AER's authority to shut-in production for conservation and the prevention of waste arises from a number of provisions within its governing legislation. Section 4(a) of the OGCA provides that one of the purposes of the Act is "to effect the conservation of, and to prevent the waste of, the oil and gas resources of Alberta." ${ }^{208}$ Section 14(1) of the REDA provides that the AER, "in the carrying out of duties and functions imposed on it by this Act or any other enactment, may do all things that are necessary for or incidental to the carrying out of any of those duties or functions." ${ }^{\text {"209 }}$ Finally, section 10(1)(aaa) of the OGCA permits the AER to make rules "generally to conserve oil and gas, and to prevent waste or improvident disposition of oil or gas, and to do any other matter reasonably incidental to the development and drilling of any oil or gas wells, the operation of them and the production from them. ${ }^{210}$ Read together, these statutory provisions grant the AER broad authority to do

Ibid at para 25 [footnotes omitted].

Bankes, "Kallisto \#2," supra note 201.

Kallisto \#2, supra note 199 at para 30.

Ibid at para 33.

Ibid at para 34

OGCA, supra note 4, s 4(2).

REDA, supra note 56, s 14(1).

OGCA, supra note 4, s 10(1)(aaa).
} 
all things necessary to prevent the waste of, and to effect the conservation of, oil and gas. ${ }^{211}$ The ABCA confirmed this authority in Giant Grosmont:

The importance of the protection of the public interest in the preservation of energy resources should be reiterated. It is not only the interests of the Appellants and Respondents that are at stake; the Board also owes a duty to the people in the Province of Alberta to safeguard their interests. It should be remembered that the Board has been entrusted with these responsibilities because it has the necessary expertise and experience to do so. As such, the Board is in the best position to balance the interests of all concerned and to make the decisions necessary to conserve the energy resources of this province. ${ }^{212}$

The EUB had multiple occasions to consider and confirm its ability to shut-in production in the name of conservation and prevention of waste in the series of decisions connected to its 1998 inquiry $^{213}$ following a request by oil sands leaseholders that the Board restrict the production of associated gas production from oil sands deposits. ${ }^{214}$ In these decisions, the Board restricted or shut-in the production of associated gas in the oil sands areas in favour of bitumen recovery. It did so on the basis that production of gas had an adverse effect on the overall recovery of bitumen. ${ }^{215}$

In addition to confirming its authority to shut-in for conservation purposes, the Board, subject to some jurisdictional restrictions, confirmed its authority to issue interim shut-in orders - akin to common law injunctions. While confirming that it did not have the authority to compel the applicant for an interim order to provide an undertaking for damages (as would be the case in most civil interim injunction applications), ${ }^{216}$ the Board set out the test for an interim shut-in order:

With respect to the appropriate test on an interim shut-in application, it is the Board's view that while the tripartite test utilized in civil litigation may offer some general guidance to the Board's deliberations, its strict application does not provide the appropriate basis upon which an interim shut-in application should be considered. The issue from the Board's perspective is one of conservation of energy resources in the public interest and, specifically, the impact of producing gas wells on the conservation of bitumen pending the outcome of the main hearing. The conservation issue will be moot at the main hearing if, for example, the ongoing pressure decline of the overlying gas zone leading up to the main hearing significantly reduces or sterilizes the ultimate recovery of the bitumen resource.

Phase 3 Proceedings Under Bitumen Conservation Requirements and Applications for Approval to Produce Gas in the Athabasca Wabiskaw-McMurray Area,(31 May 2004)2004-045 at 2-3, online: EUB $<$ https://www.aer.ca/documents/2004/2004-045.pdf> [Decision 2004-045].

Giant Grosmont, supra note 131 at para 45.

EUB Inquiry, Gas/Bitumen Production in Oil Sands Areas, March 1998 as cited in Allan E Ingelson, ed, Canada Energy Law Service, (Toronto: Carswell, 2007) (loose-leaf, consulted on 7 April 2015) § 448a. See e.g. Decision 2000-21, supra note 179 at 6; Gulf Canada Resources Limited Request for the Shut-in of Associated Gas, Surmont Area (30 March 2000), 2000-22 at 4, online: EUB <www.aer.ca/ documents/decisions/2000/2000-22.pdf>; Petro-Canada Oil and Gas Interim Shut-in of Gas Production: Chard Area (2 August 2001), 2001-63 at 3-5, online: EUB <www.aer.ca/documents/ decisions/2001/2001-63.pdf> [Petro-Canada Oil]; Applications for the Production and Shut-in of Gas: Chard Area and Leismer Field (18 March 2003), 2003-023, online: EUB <www.aer.ca/ documents/decisions/2003/2003-023.pdf>; Decision 2004-045, supra note 211 at 2-3; Gas Over Bitumen Decisions, supra note 159 at 2.

See e.g. Ingelson, supra note $213, \S 448$ a.

Petro-Canada Oil, supra note 214 at 4, as cited in Ingelson, ibid. 
An interim shut-in application does not require irreparable harm to be established conclusively or that the Board conduct an analysis of the balance of convenience between the parties regarding the shut-in of gas. Where it appears to the Board that bitumen recovery may be affected by gas production, the Board may take such conservation action that it deems necessary. This is not to say that on an interim basis the nature of the potential competing harm to the parties is not a relevant consideration, only that the Board is not bound to apply the strict tripartite test in determining whether to grant an interim shut-in order. The Board's focus is centred on the potential for the significant waste of bitumen resources during the period required to consider the main shut-in application. ${ }^{217}$

Albeit for the purposes of the conservation of bitumen, which is afforded priority pursuant to the Oil Sands Conservation Rules, ${ }^{218}$ the AER's test and consideration of its conservation and prevention of waste is illustrative for the purposes of subsurface communication disputes caused by hydraulic fracturing. It shows that the Board not only has the power to shut-in, but also has the power to issue interim shut-in orders pending resolution of the dispute.

\section{APPLICATION OF SHUT-IN ORDERS TO SUBSURFACE COMMUNiCATION DisPUTES}

It remains uncertain whether the propagation of fractures beyond the boundaries of a licensee's lease in such a way as to create communication where none previously existed and where this causes damage or a risk of damage to the owner or working interest owner of adjacent minerals can be the basis of an application to the AER for a shut-in order. Alternatively, can the licensee argue that the propagation of fractures outside its lease area is necessarily incidental to the proper working of shale deposits? The split-title and the Gas Over Bitumen Decisions provide guidance with respect to how the AER will approach production disputes from subsurface communication. From these decisions, it seems possible to say the following:

- In the case of subsurface communication with an existing storage scheme, if it is found that storage gas is being produced, the AER will shut-in production. ${ }^{219}$ In Kallisto \#1, the AER held that if the well in question was found to be in communication with the storage reservoir, it would shut-in this well without any fracture stimulation to prevent harm of communication or conversion of the storage gas. ${ }^{220}$ Although the Board did not expressly rely on section 16 of the OGCA, one can extrapolate that the production of storage gas could constitute production contrary to this section.

- The AER will assess the risk of subsurface communication and will seek to manage such risks through ongoing testing, monitoring, and reporting. ${ }^{221}$

- There is an argument that hydraulic fracturing is a necessary method for the production of tight oil and gas. On this basis, the potential for fractures to result in the production

Petro-Canada Oil, ibid at 4.

Oil Sands Conservation Rules, Alta Reg 76/1988 (which states that "[w] here it appears to the Regulator that the ultimate recovery of crude bitumen in the oil sands strata may be affected by gas production, the Regulator may, on its own initiative or on application by an affected party, make any order or directive it considers necessary to effect the conservation of the crude bitumen in any particular case," s 3(5)). Kallisto \#1, supra note 168 .

Ibid.

Ibid at paras 72-82, Appendix 1; Kallisto \#2, supra note 199 at paras 96-100. 
of hydrocarbons originating outside the leased area is not contrary to section 16 of the OGCA. Instead, it is a known and inevitable consequence and therefore an implied term of the applicable lease. ${ }^{222}$

- Regardless of entitlement pursuant to the lease, the AER has the authority to shut-in or restrict production on the basis of conservation and to prevent waste. ${ }^{223}$

- The AER's practice is to encourage production sharing agreements through the conditions it attaches to approvals. This practice indicates a preference for parties to determine the apportionment and value of any hydrocarbons produced. Further, the fact that the AER indicates that the hydrocarbons can be measured, and damages subsequently determined in the courts, implies that the rule of capture may not apply. In other words, if the rule of capture applied to these situations, there would be no need to account to the other party for the cross-flow hydrocarbons.

While the threat of a shut-in order provides motivation to a licensee to endeavour to ensure fractures remain within the intended zones, it is only a temporary fix. Shutting-in production may not accord with the public interest to ensure orderly development, conservation, and prevention of waste. Further, as stated by the courts in dicta, and consistent with the AER's approach, equitable considerations for the production of oil or gas to which another party holds the interest can typically be quantified and compensation provided in the form of monetary damages. ${ }^{224}$ As a result, the shut-in should arguably be temporary until the AER addresses the issue, for instance by mandating pressure monitoring and testing, issuing a commingling order, or encouraging a production sharing agreement.

While the AER's power to shut-in, suspend, or restrict production seems like a powerful incentive for industry to ensure fractures remain within the intended zones, the usefulness of this regulatory tool depends upon the ability to prove that a fracture actually crossed the permitted boundary, or that the integrity of the well completion was the cause of the communication issues. In order to prove such events, key technical information is required, including with respect to historical practices, gas composition, reservoir pressures, the geology, fracture propagation modelling, and the current and historical development within the area including abandoned and suspended wells. Therefore, the AER's power to compel disclosure, monitor production and operational matters, and impose conditions on licences becomes critical in setting the stage for determining communication or cross-flow issues and how they can be resolved.

224 See also Anderson v Amoco Canada Oil and Gas, 2011 ABCA 268, 2011 ABCA 268 (CanLII); Nigel Bankes, “Accounting Issues Left Unresolved in Split Title Litigation" (14 October 2011), ABlawg (blog), online: <ablawg.ca/wp-content/uploads/2011/10/blog_nb_anderson_oct2011.pdf> [Bankes, "Accounting Issues"]. The Anderson saga came to an end pursuant to Rule $2 \overline{4} 4.1$ of the Alberta Rules of Court, Alta Reg 390/1968, as repealed by Alberta Rules of Court, Alta Reg 124/2010, by virtue of no steps being taken by the plaintiff to materially advance the action. This left many questions unanswered, including: (1) whether the petroleum owners owe a duty of care to account for the gas produced; (2) whether the gas owners have an action in tort; (3) what costs should be included within an accounting claim; (4) whether the petroleum owner(s) (and its lessees) have a duty not to flare the gas owner's gas (where flaring can be reasonably avoided); and (5) how the onus of proof issues should be dealt with. 


\section{Production Sharing Agreements}

While there is no statutory authority for mandatory production sharing agreements, the jurisprudence recognizes that the AER has a practice of encouraging them. ${ }^{225}$ Further, one can also speculate that the absence of a significant number of decisions by the AER addressing subsurface reservoir communication issues is partly due to parties settling prior to the hearing and decision by the Board. As discussed above, the Board's conditioning of Kallisto's approvals in Kallisto \#1 and Kallisto \#2 supports the proposition that the Board will continue its practice of encouraging settlements by imposing conditions dealing with monitoring and testing as a part of its approvals.

While it may be the preference of the Board that parties resolve subsurface communication issues through private agreements, the failure to reach such an agreement does not prevent a party from seeking recourse from the AER or the courts. As discussed above with respect to Goodwell:

\footnotetext{
Production-sharing agreements define the basis on which parties contribute to well costs and receive compensation for produced hydrocarbons. Such agreements are obviously desirable when mineral rights overlap, as they permit interested parties to negotiate and structure their economic arrangements without third party involvement. However, it is one thing to recognize the desirability of and encourage parties to sign a production-sharing agreement; it is another to conclude that a lessee has no right to produce without one. Disagreements about production frequently occur, and are even recognized in the energy legislation. Parties are entitled to come to court to resolve difficult disputes. Failure to reach a negotiated production-sharing agreement does not extinguish anyone's rights.
}

The Board's practice of requesting a production-sharing agreement in split title situations does not support the conclusion that the oil sands lessee has no right to produce initial gas-cap gas incidental to bitumen recovery without the natural gas lessee's consent. Such a restriction should either be plainly stated in the oil sands leases, and echoed in the permits and well licences, or in an amendment to the Alberta energy legislation. $^{226}$

This decision may be applied to subsurface communication and the incidental production of oil and gas as between licensees within the same reservoir or neighbouring reservoirs. While the AER can strongly encourage such agreements to resolve communication issues, without legislative amendments, it cannot require such an agreement.

The primary reason for encouraging settlement appears to be the underlying concept that any produced oil or gas can be measured and monetary compensation can be paid for the hydrocarbons produced. The Alberta Court of Appeal has also confirmed that the harm caused by the production of another's resource can be quantified and financial compensation awarded. In Nexxtep Resources Ltd. v. Talisman Energy Inc. ${ }^{227}$ the Alberta Court of Appeal denied, among other things, an application by Nexxtep Resources Ltd. (Nexxtep) for summary judgment and an injunction requiring Talisman Energy Inc. (Talisman) to shut-in a vertical well due to a dispute over whether the rights to the well and the formation it was 
producing from were included within the parties' purchase and sale agreement. Although this case was about confusion over the assets included within a purchase and sale agreement and not subsurface communication, it is instructive because the Court denied the injunction application on the basis that there was no irreparable harm. ${ }^{228}$ In other words, if Talisman was in fact producing Nexxtep's gas, the harm to Nexxtep could be quantified and compensated for by monetary damages. ${ }^{229}$ Therefore, in the context of communication issues, any damages or harm could be quantified and compensated for. However, as stated above, this process falls outside the jurisdiction of the AER, which is limited to remedies such as requiring monitoring, testing, reporting, and disclosure of the operational and technical results in an effort to encourage settlement, and to provide the requisite evidence upon which the courts can adjudicate.

Therefore, while it is open to the parties to negotiate a settlement or production sharing agreement where communication issues arise from a practical perspective, reaching such an agreement will require a common understanding regarding the existence of communication, its causes, and the composition, quantity, and ownership of the oil and gas being produced. The information necessary to reach such an understanding may not be readily available to the parties, notwithstanding the AER's willingness to impose conditions requiring monitoring and testing of well and reservoir conditions and disclosure of the results. These practical realities make negotiating the commercial terms of a production sharing agreement in any given circumstance challenging.

One commentator provides the following summary of the AER's preference within the context of Kallisto \#2:

The parties expressed very divergent views on how to deal with the possibility that Kallisto's well might produce storage gas. In crafting its response the AER recognized that it faced some jurisdictional constraints in terms of any solution that it might impose. Consequently, the AER focused on imposing a set of requirements that would provide the parties with an information base that would help them reach a voluntary agreement, or, alternatively, provide a basis for resolving any remaining issues through litigation. To that end, the AER imposed a set of conditions including a requirement to conduct an initial pressure test, and a set of measurement and reporting requirements the effect of which the AER summarized as follows (at para 107):

The panel also finds that measurement conditions placed on the licence will ensure that the parties have the information they need to identify the nature of fluid produced at the 16-26 well and reach an arrangement, either voluntarily or through the courts, that reflects the rights and interests of each party.

While the AER indicated that Kallisto had a duty to return to CrossAlta any storage gas that it might produce (at para 97), it declined to impose a specific condition to that effect or indicate a particular mechanism for effecting such a return. It did however comment on Kallisto's proposals finding them "reasonable" and noting in particular (at para 99) "that if Kallisto presupplied gas to CrossAlta's gas storage unit in quantities greater than or equal to the heating value of the gas produced, the gas produced from the 16-26 well could be considered its own and not that of any other gas owner." The AER however did not believe that it had the jurisdiction to impose such a solution and offered detailed reasons for that conclusion, examining a number 
of different possible sources of authority under the Oil and Gas Conservation Act, RSA 2000, c O-6 $(O G C A){ }^{230}$

The issue of whether subsurface communication is occurring and its cause is highly technical and the AER, as a highly specialized expert tribunal, is in a better position than the courts to adjudicate whether communication issues exist and whether hydraulic fracturing caused them. However, as acknowledged in the jurisprudence, the issue of compensation and ultimate ownership over the produced substances can only be addressed through the courts. This leaves industry with the burden of pursuing parallel proceedings with the AER and through the common law to achieve a full solution. This bifurcated process is a strong motivator for settlement as between industry, and encourages the negotiation of production sharing or other forms of compensation agreements. However, where the parties cannot reach an agreement, the limits of the AER's jurisdiction make for complicated regulatory and court processes. These limits of the AER's jurisdiction may be one reason behind the play-based approach proposed within the Unconventional Framework.

\section{E. Testing, Monitoring, AND REPORTING OBLIGATIONS}

As stated above, a well cannot be drilled, and preparatory and incidental activities cannot be undertaken, without the requisite licence from the AER, ${ }^{231}$ which may be subject to any conditions, restrictions, or stipulations that the AER considers appropriate. ${ }^{232}$ In addition, pursuant to section 10 of the OGCA the AER can, among other things, prescribe rules "for the calculation of allowables, maximum production rates, penalty factors, penalties and overproduction status," 233 and generally "do any other matter reasonably incidental to the development and drilling of any oil or gas wells, the operation of them and the production from them."234

All of the regulatory tools discussed in this article require sufficient technical data regarding the subsurface communication, its causes, and the composition and origin of the produced hydrocarbons. Compelling operational controls and the provision of operational data are powerful tools for resolving subsurface communication disputes, both for the AER and as between parties. As between industry parties, information regarding production can be confidential. Without regulatory process, such information may not be shared between the disputing parties. For the industry parties, the sharing of subsurface communication data is extremely relevant for the purpose of a production sharing agreement or other settlement.

For example, in Kallisto \#1, the ERCB assessed the risk of communication between Kallisto's proposed well and CrossAlta's gas storage facility, and attempted to mitigate the risk of communication by imposing conditions on the approval. Specifically, the Board imposed a requirement for pressure testing to be completed, the results of which would form the basis of how the parties would proceed. If the well was a dry hole, the well would be 
abandoned, and there would be no harm to CrossAlta. ${ }^{235}$ If it was not a dry hole, the Board imposed pressure testing to establish the reservoir pressures and to determine whether such pressure data would indicate existing communication. If the pressure testing data demonstrated the existence of communication, the Board was prepared to shut-in the well without any fracture treatment. In the event that the reservoir pressure was found to be virgin reservoir pressure, the Board would allow Kallisto to perform fracture treatment, provided such treatment was limited to 40 tonnes or less. ${ }^{236}$

Another example is Kallisto \#2, where the AER imposed measurement conditions on the licence with the intention of ensuring the parties have the information they need to identify the nature of the fluid produced in order to reach a production sharing agreement. ${ }^{237}$

By attaching conditions to its approvals and licences dealing with such matters as gas composition testing, micro seismic testing, or proppant tracer studies (for vertical wells), the AER can build its library of information. This includes information regarding each play, practices of operators, the composition of gas from various reservoirs, fracking fluid compositions, and any potential well integrity issues. This appears to be the intention behind the play development plans under the Unconventional Framework, which require industry cooperation and information sharing.

This relates back to the AER's assessment of risk. The default position appears to be to allow the production of the resources, and when there is a potential for communication, to ensure adequate production controls and monitoring are in place to set the foundation for either voluntary or court-ordered agreements for compensation.

\section{F. COMMINGLing ORDERS}

The AER defines "commingled production" as "production of oil and gas from more than one pool or zone through a common wellbore without separate measurement of the production from each pool or zone." ${ }^{, 38}$ Commingled production is regulated in accordance with sections 3.050 and 3.060 of the OGCR:

3.050(1) The Regulator may, by order, approve two or more pools in a field as pools from which production may be taken or to which injection may be made without segregation in the well bore, and may, where in its opinion exceptional circumstances so require, limit the application of the order to production or injection in wells named in the order.

(2) An application for an order under this section must be made in accordance with Directive 065 and must include any other information that the Regulator requires. 
3.060 A well shall not be completed or operated with casing perforated or left open in more than one pool unless

(a) such completion or operation occurs in accordance with the requirements of section 3.040 or 3.050 , or

(b) the commingling is in compliance with section $3.051 .^{239}$

According to AER Directive $065,{ }^{240}$ commingling or the segregation of production in the wellbore is regulated, among other things, in order to avoid wellbore or reservoir conditions that may adversely affect recovery, ensure operational safety, and gather data for resource evaluation and reservoir management. ${ }^{241}$

A commingling order was requested by Canadian Natural Resources Limited (CNRL) and ConocoPhillips Canada Operations Ltd. (Conoco) in the proceedings leading up to the ERCB Decision. ${ }^{242}$ In this case, CNRL and Conoco objected to the Surge Energy Inc. (Surge) application to suspend drilling spacing units and target areas and establish holdings for the production of oil from the Doig Formation. In its evidence, CNRL submitted that if Surge's wells drilled in the Doig Formation were completed with multiple fractures, those fractures would propagate into the Halfway formation (to which it and Conoco held rights) and create a direct path or cross flow of gas. ${ }^{243}$ In addition to requesting monitoring and production controls (including conditions attached to fracture procedures), CNRL requested that the Board deny Surge's holding application and deny the applied for well licence until a commingling order was approved under a gas return agreement between the owners. ${ }^{244}$ Unfortunately, the Board did not consider how a commingling order might address these potential communication issues because the parties reached a settlement and CNRL and Conoco withdrew their objections. ${ }^{245}$

Requesting a commingling order could be another regulatory tool used by industry if faced with harm from potential communication caused by hydraulic fracturing. While there is no question, given sections 3.050 and 3.060 and Directive 065, that the AER has the authority to issue commingling orders, the availability of a commingling order will be limited to those factual circumstances meeting the statutory requirements, or where the casing perforations are located in more than one pool or zone.

\section{G. SubSURFACE ORDERS}

As briefly discussed above, the AER also has the power ${ }^{246}$ to designate subsurface orders under section 11.104 of the OGCR. ${ }^{247}$ Section 11.104 of the OGCR is targeted at the development of tight oil and gas resources and intended to permit the AER to tailor

OGCR, supra note 66, ss 3.050, 3.060 .

Directive 065, supra note 4, s 3.1.

Ibid, s 3.1.1.

Surge Energy Inc, supra note 3 (Evidence, Exhibit 104.01, CNRL 10 December 2012 at para 1.7).

Ibid at para 1.6.

Ibid at paras 1.6-1.9.

Ibid at para 12 .

OGCA, supra note 4 , ss $7,9$.

Bulletin 2015-05, supra note 83. 
regulatory requirements for specific geological zones over specified areas to better suit the resource being developed. ${ }^{248}$

11.104 Notwithstanding sections 3.050, 3.051, 3.060, 4.021, 4.030, 4.040, 7.025, 10.060, 11.010, 11.102 and 11.145, if the Regulator is satisfied that it is appropriate to do so, the Regulator may, on its own motion, issue a subsurface order that

(a) designates a zone in a specific geographic area, and

(b) prescribes requirements pertaining to spacing, target areas, multi-zone wells, allowables, production rates and other subsurface matters within that zone,

in which case if there is a conflict or inconsistency between the subsurface order and any of the sections referred to above, the subsurface order prevails to the extent of the conflict or inconsistency. ${ }^{249}$

These subsurface orders can be used to prescribe requirements related to completion operations including the use of hydraulic fracking. In determining whether it is appropriate to issue a subsurface order, the AER will "include an evaluation of risks to resource recovery and reservoir equity." ${ }^{, 50}$ This broad language indicates that subsurface orders could be used to impose conditions to manage subsurface communication (that is, through measures such as allowables, production rates, and permitting multi-zone wells) and are likely an intended complement to the AER's recent "experimentation with [a] play-based approach" for the development of unconventional resources. ${ }^{251}$

As of the date of this article, the AER has issued three subsurface orders. ${ }^{252}$ Generally, these orders provide variances on the standard requirements for operational parameters such as well density restrictions, target areas for wells, and reporting and testing requirements. These variances appear to provide greater flexibility and discretion to the operators in the area. ${ }^{253}$ With respect to hydraulic fracturing, Subsurface Order No. 2 imposed a number of requirements for the use of hydraulic fracturing in the Duvernay Zone intended to detect and monitor against potential seismic events caused by or resulting from hydraulic fracturing within the area. ${ }^{254}$

With respect to disputes between competing industry parties, a subsurface order could be used to impose restrictions applicable to all parties and future applications within the

Ibid (the AER indicates that these orders "will only address resource regulatory matters that are under the AER's jurisdiction. Where the orders allow increased well density, these orders will not in any way predetermine regulatory approval of wells, pipelines, other production facilities, access roads, and other surface disturbances associated with energy resource development of the geological zones defined in the order" at 1). See e.g. Subsurface Order No 1, supra note 84; Subsurface Order No 2, supra note 84; Subsurface Order No 3, supra note 84. OGCR, supra note 66, s 11.104.

Bulletin 2015-05, supra note 83 at 1.

Nigel Bankes, "The AER and the Values of Efficiency, Flexibility, Transparency and Participation: Best in Class?" (12 February 2015), ABlawg (blog) at 1, online: <ablawg.ca/wp-content/uploads/2015/02/ Blog_NB_AER_Feb2015.pdf $>$.

Subsurface Order No 1, supra note 84; Subsurface Order No 2, supra note 84; Subsurface Order No 3 , supra note 84 .

See e.g. Subsurface Order No 1, ibid, ss 2(a)-(b) (this section provides that there are no well density restrictions, giving licensees the freedom to drill where they would like without the burden of multiple well applications to the AER).

Subsurface Order No 2, supra note 84, s 2. 
specified geological zone and area. Perhaps, subsurface orders could be a tool to assist in resolving disputes, and could be agreed upon by industry as part of the resolution process; or, could originate as a result of a hearing or negotiations on a particular development application.

\section{CONCLUSION}

The current regulatory framework equips the AER and industry with procedural steps to access the regulatory tools to resolve subsurface communication disputes. First, industry can monitor applications by other operators that could affect their operations, and can participate in the application process by filing a statement of concern. Where communication is suspected and the applications have already been approved, industry can file an application for the AER to review and vary the applicable approval(s). In addition, the AER has a process for receiving and investigating complaints, which could also be used to trigger an investigation by the AER. ${ }^{255}$

When faced with these concerns and objections by industry, the AER then has the options (to the extent that each may be applicable) to shut-in or suspend operations, order mandatory testing, monitoring and reporting, implement a commingling or subsurface order, or deny development application.

How these tools will be used by the AER, including the conditioning of approvals and the potential shut-in of production, depends upon the classification of the cause of the communication and whether fractures propagating beyond legal boundaries are necessarily incidental to the production of the resource in question.

Although the AER cannot impose production sharing agreements under its governing legislation, the AER's practice is to encourage them through the conditions it attaches to approvals. This practice indicates a preference for parties to determine the apportionment and value of any hydrocarbons produced. The fact that the AER indicates that the hydrocarbons can be measured, and damages subsequently determined in the courts, implies that the rule of capture may not apply. In other words, if the rule of capture applied to these situations, there would be no need to account for the cross-flow hydrocarbons to the other party. ${ }^{256}$ Further, whether the rule of capture applies will likely depend upon the specific facts, but as stated in connection with Borys and Anderson, communication between reservoirs or containers is very different than communication within the same container where the rule of capture traditionally applies.

Even with these potential solutions, when it comes to determining communication issues, there are some areas that fall outside of the AER's jurisdiction and that will require disputing parties to seek recourse through the courts (actions in tort, negligence, contract, strict applications-and-notices/file-a-complaint $>$.

256 See Bankes, "Accounting Issues," supra note 224 (it is the difference between the right to work and ownership). 
liability) or alternative dispute resolution. ${ }^{257}$ The following are examples of powers that fall outside the AER's statutory jurisdiction:

- While the AER may determine whether cross-flow between wells, formations, or reservoirs (water or oil and gas) is in fact occurring, determining the quantum of compensation is a matter for the courts.

- While the AER may recognize the desirability of and encourage parties to sign a production sharing agreement, it cannot, where the failure to reach such an agreement would effectively extinguish one party's rights, require such an agreement. ${ }^{258}$ The question remains whether the play-based development plans could in effect be used to implement production sharing agreements, depending upon the scope of the risk management plan and whether any existing communication issues exist with respect to the play.

Regardless of whether the dispute is being settled privately, by the AER, or by the courts, a further challenge is the "information gap" or heavy burden of establishing that communication is occurring and hydraulic fracturing was the cause. Hydraulic fracturing occurs far below the surface, "where only equipment under the control of operators can observe it. $" 259$ This has been described as information asymmetry, in that private parties have better access to information than the regulator and the level of expertise as between operators can vary greatly. ${ }^{260}$ This adds to the technical challenges in proving that hydraulic fracturing causes subsurface reservoir communication issues and that communication or cross-flow is in fact occurring.

Given the widespread use of multistage horizontal hydraulic fracturing, it is anticipated that issues related to subsurface communication will continue to be raised with the AER to date and in the courts. With respect to how these issues will be resolved, the AER has attempted to manage risk through monitoring and testing. Generally, the AER has permitted development to occur by endorsing an approach which relies on the implicit rights attached to known and inevitable consequences to mining and recovering the minerals. This approach has been justified on the basis that any production of another's minerals does not result in irreparable harm, but rather damages which can be identified and quantified.

In addition to the contractual alternative dispute resolution processes that may be agreed upon by contracting parties, the AER has a formal alternative dispute resolution process. See Alberta Energy Regulator, "Alternative Dispute Resolution Program and Guidelines for Energy Industry Disputes," Manual 004 (Calgary: AER, July 2013).

259 Sheila Olmstead \& Nathan Richardson, "Managing the Risks of Shale Gas Development Using Innovative Legal and Regulatory Approaches" (2014) 39:1 Wm \& Mary Envtl L \& Pol'y Rev 177 at 181-82 [footnotes omitted]. 